\title{
Provenance of tetraether membrane lipids in a large temperate lake (Loch Lomond, UK): implications for glycerol dialkyl glycerol tetraether (GDGT)-based palaeothermometry
}

\author{
L. K. Buckles ${ }^{1}$, J. W. H. Weijers ${ }^{1, *}$, X.-M. Tran ${ }^{1}$, S. Waldron ${ }^{2}$, and J. S. Sinninghe Damsté ${ }^{1,3}$ \\ ${ }^{1}$ Department of Earth Sciences, Utrecht University, Utrecht, the Netherlands \\ ${ }^{2}$ Department of Geographical and Earth Sciences, University of Glasgow, Glasgow, UK \\ ${ }^{3}$ NIOZ Royal Netherlands Institute for Sea Research, Department of Marine Organic Biogeochemistry, \\ Den Burg, the Netherlands \\ *now at: Shell Global Solutions International B.V., Rijswijk, the Netherlands
}

Correspondence to: J. S. Sinninghe Damsté (damste@ nioz.nl)

Received: 16 January 2014 - Published in Biogeosciences Discuss.: 17 March 2014

Revised: 18 August 2014 - Accepted: 1 September 2014 - Published: 9 October 2014

\begin{abstract}
The application of glycerol dialkyl glycerol tetraether (GDGT)-based palaeoenvironmental proxies, such as the branched vs. isoprenoidal tetratether (BIT) index, TEX $_{86}$ and the MBT-CBT palaeothermometer, has lately been expanded to lacustrine sediments. Given recent research identifying the production of branched, bacterial GDGTs (brGDGTs) within lakes, it is necessary to ascertain the effect of this lacustrine production on GDGT-based proxies. This study profiles a temperate, monomictic lake (Loch Lomond, UK), analysing labile intact polar GDGT lipids (IPLs) and resilient core GDGT lipids (CLs) in catchment soils, small tributary rivers, lake water and lake sediments.

Loch Lomond consists of two basins bisected by the Highland Boundary Fault, resulting in a mesotrophic to oligotrophic gradient from south to north. The north basin is fjord-like, while the south basin is shallow with a lowland catchment. Besides abundant influxes of allochthonous soiland peat-derived (CL) brGDGTs, brGDGTs are produced in a variety of settings in Loch Lomond. Rather than integrating a scattered soil signal, there is some evidence that small rivers may contribute to the brGDGT pool through addition of brGDGTs produced in situ in these streams. Three hundred days of settling particles and water column profiles of suspended particulate matter (SPM; March and September 2011) reveal brGDGT production throughout the water column, with (IPL and CL) brGDGT distributions varying by basin. In lake sediments, in situ brGDGT production affects
\end{abstract}

the distributions of sedimentary brGDGTs despite high soiland peat-derived organic matter influxes from the catchment.

MBT-CBT-derived mean annual air temperature (MAAT) estimates from soil, river and lake sediments vary widely. A strong bias towards higher MAATs in the south and lower MAATs in the north basin further complicates the application of the proxy. These results emphasise that caution must be exercised when applying the MBT-CBT palaeothermometer to individual lakes in which the use of the proxy has not been validated and therefore the factors affecting its application are not well understood. Despite elevated BIT indices, (partly) due to in situ brGDGT production, reliable $\mathrm{TEX}_{86}$ lake surface temperature (LST) estimates were obtained from SPM with BIT indices up to 0.9. Lower north basin sediments yielded accurate LST estimates but require further evaluation to properly constrain the application of the $\mathrm{TEX}_{86}$ proxy.

\section{Introduction}

Palaeoclimate reconstructions are essential for our understanding of climate dynamics and the factors that affect them and hence are important in order to project future climate change with greater reliability. Oceanic palaeoclimate reconstructions, however, far exceed those from the continental realm, partly due to discontinuous continental records but 
also due to a lack of quantitative proxies for continental air temperature. A relatively new quantitative temperature proxy is based on the proportions of bacterially derived branched glycerol dialkyl glycerol tetraether (brGDGT) membrane lipids in soils. The relative amount of cyclopentane moieties and methyl branches contained in these membrane lipids, expressed in the cyclisation and methylation indices of branched tetraethers (CBT and MBT, respectively), are related to soil $\mathrm{pH}$ and mean annual air temperature (MAAT) (Weijers et al., 2007a; Peterse et al., 2012). Upon soil erosion these compounds are transported to the marine realm, and the MBT-CBT proxy has therefore been successfully applied to near-coastal marine sediments containing considerable terrestrial organic matter to reconstruct river basin integrated continental MAAT (e.g. Weijers et al., 2007b, c; Schouten et al., 2008). In order to extend the continental coverage of temperature reconstructions, application of the MBT-CBT proxy to potentially high-resolution lacustrine sediment records is a logical step.

However, distributions of brGDGTs in lake surface sediments showed a general mismatch with those in surrounding soils, and reconstructed MAATs from lake surface sediments were found to generally underestimate instrumental temperatures, when applying the soil-based MBT-CBT calibration. This suggests that additional production of these compounds within the lake system must occur (e.g. Sinninghe Damsté et al., 2009; Tierney and Russell, 2009; Bechtel et al., 2010; Blaga et al., 2010; Tierney et al., 2010; Tyler et al., 2010; Zink et al., 2010; Sun et al., 2011; Sinninghe Damsté et al., 2012). Although several local and regional MBT-CBT calibrations based on lake surface sediments have been produced in an effort to eliminate this offset (e.g. Tierney et al., 2010; Zink et al., 2010; Pearson et al., 2011; Sun et al., 2011; Loomis et al., 2012), an improved understanding of the source(s) of the brGDGTs produced in the lake system is necessary to better constrain the applicability of the MBT-CBT palaeothermometer to lake sedimentary archives.

As there are no known producers for all but one of the brGDGTs used in the MBT-CBT palaeothermometer (Sinninghe Damsté et al., 2011), it is not possible to trace brGDGT producers through the application of molecular ecological techniques. However, through the introduction of a method by Pitcher et al. (2009a) to separate intact polar GDGT lipids (IPL GDGTs) from core GDGT lipids (CL GDGTs), it has become possible to use IPLs to trace living, GDGT-producing bacteria and archaea in the environment (e.g. Pitcher et al., 2009b, 2011b; Lengger et al., 2012; Schouten et al., 2012; Gibson et al., 2013; Buckles et al., 2013). Although there is some discussion as to how quickly IPLs degrade in sediments, especially concerning the less labile glycosidic head groups (e.g. Lipp and Hinrichs, 2009; Bauersachs et al., 2010; Schouten et al., 2010; Lennger et al., 2012; Xie et al., 2013), their application in an extant environment to describe current biomass should not be affected (e.g. Pitcher et al., 2011a; Buckles et al., 2013).
A study of Lake Towuti, Indonesia, previously suggested the presence of in situ production within the lake based on differences in brGDGT distribution between soils and sediments (Tierney and Russell, 2009). Similarly, a study of brGDGT distributions and concentrations in isolated soil and sediment sampled from a range of Ugandan lakes came to the same conclusion (Loomis et al., 2011). More recently, a detailed modern study of GDGT distributions in the permanently stratified, partially anoxic Lake Challa (eastern Africa) found that brGDGTs were produced within both the oxic and anoxic water column and found some evidence suggestive of their production in sediments (Buckles et al., 2014). In the case of the small, shallow Sand Pond (RI, USA), it was considered that more highly methylated brGDGTs may be produced within the predominantly suboxic sediments (Tierney et al., 2012). However, in the high Alpine Lake Cadagno (Switzerland), no evidence of brGDGT in situ production was found (Niemann et al., 2012).

With few exceptions, the individual lakes that have been studied for their brGDGT content are characterised by one or more of the following properties: located at low latitudes; a relatively restricted catchment area to minimise the influence of soil-derived brGDGTs; and suboxic to anoxic bottom waters (e.g. Tierney and Russell, 2009; Loomis et al., 2011; Niemann et al., 2012; Tierney et al., 2012; Buckles et al., 2014). In order to further investigate the apparently widespread production of brGDGTs in lacustrine environments and its potential impact on GDGT-based proxies, it is also necessary to examine temperate lakes with larger catchment areas, relatively high soil organic matter inputs and oxygenated water columns. Loch Lomond is a temperate, monomictic lake, with a large and peat-rich catchment, located near Glasgow (Scotland, UK; Fig. 1). Here, we examined Loch Lomond in detail by analysing the distributions of core and intact GDGT lipids in soils and small tributary streams around the lake, in suspended and sinking particulate matter within the lake and in lake surface sediments. The obtained results further constrain the sites of brGDGT production in lake systems and provide insight into the abundance of lake-derived brGDGTs relative to soil-derived brGDGTs. With that information, the potential and limits for application of the MBTCBT palaeothermometer as well as other GDGT-based proxies to lacustrine sediment archives can be better constrained.

\section{Methods}

\subsection{Site characterisation}

Loch Lomond is the largest freshwater lake in the UK. It is a monomictic lake that lies at ca. $8 \mathrm{~m}$ elevation between latitude $56^{\circ}$ and $56^{\circ} 19^{\prime} \mathrm{N}$ and longitude $4^{\circ} 30^{\prime}$ and $4^{\circ} 43^{\prime} \mathrm{W}$, ca. $30 \mathrm{~km}$ north-west of Glasgow, UK (Fig. 1; Maitland et al., 2000). The lake's surface area covers $71 \mathrm{~km}^{2}$, with a large 


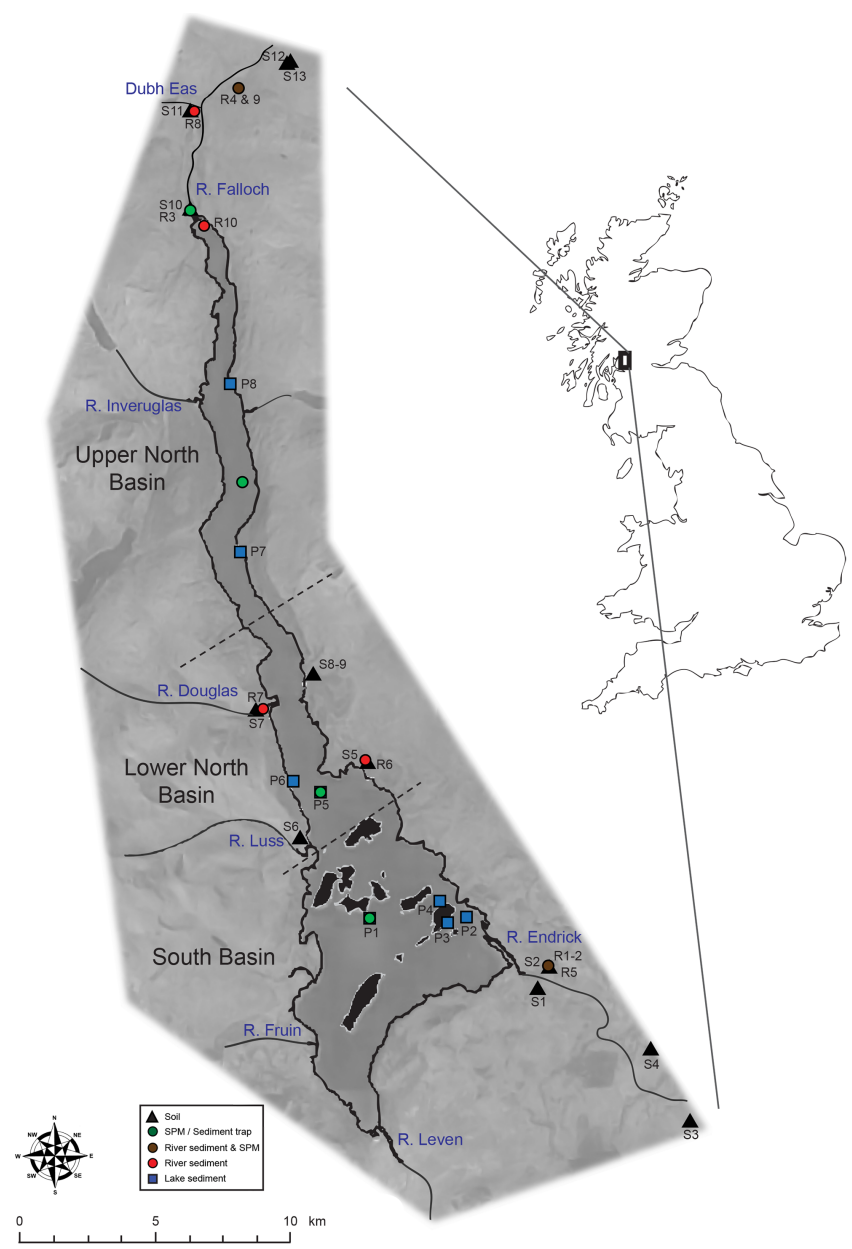

Figure 1. Map of Loch Lomond and coded sample locations (see Tables 1-5). Black patches in the south basin represent islands; black boxes and their associated labels at the sediment trap and SPM locations (green circles) refer to the sediment collected from the same location. The extent of catchment rivers is represented by smoothed lines.

catchment area of $780 \mathrm{~km}^{2}$ (Maitland, 1981). Since the Highland Boundary Fault passes through south Loch Lomond, the lake is split into two distinct basins (e.g. Pierce, 1999). The north and south basins contain different geology, land uses and soil within their catchment areas (Maitland, 1981). The north basin is oligotrophic and fjord-like; it is long $(20 \mathrm{~km})$, narrow $(\max 1.5 \mathrm{~km})$, deep $(\max 190 \mathrm{~m})$ and has a mountainous catchment area (Smith et al., 1981b). Inveruglas Water and the River Falloch are the main rivers draining into the north basin, with a combined catchment of $271 \mathrm{~km}^{2}$; multiple smaller rivers/streams also flow into the north basins, including Douglas Water. The River Falloch enters Loch Lomond at its northern point and flows from higher-altitude terrain into the lake (Fig. 1). The generally base-poor soils of this catchment area include alpine soils and rankers on high ground, peat and peaty gleys at intermediate elevations and humus- iron podzols can be found on lower ground (Bayfield and Conroy, 1995). In terms of land use, this northern catchment area is dominated by sheep grazing (Eurolakes, 2001), with a far smaller proportion used in forestry. The south basin is mesotrophic, broader $(\max 8.8 \mathrm{~km})$ and shallow $(\max 20 \mathrm{~m})$ and contains multiple small islands (Smith et al., 1981a). Endrick Water is the main inflow to the south basin and drains $264 \mathrm{~km}^{2}$ of generally base-rich lowlands with large areas of brown forest soils, as well as peaty gleys and podzols found on higher ground (Bayfield and Conroy, 1995). Endrick Water is a meandering river that flows through relatively lowlying land, carrying silt and other material into the south-east of Loch Lomond, while the River Fruin flows into the southwest of the lake with a smaller catchment of $161 \mathrm{~km}^{2}$. The full south lake catchment is more densely populated (Maitland, 1981) than the northern catchment and contains more urban development. Around a quarter of this catchment is used as arable farmland and roughly half as rough grazing; a small proportion is also used as forestry (Eurolakes, 2001). The main outflow of Loch Lomond, the River Leven, is also located at the south basin. A barrage is operated on the River Leven outflow; the river is ca. $10 \mathrm{~km}$ long and discharges into the River Clyde, south of Loch Lomond (Eurolakes, 2001). As a consequence, the hydrology of the south basin of Loch Lomond is dominated by the throughflow of Endrick Water (Fig. 1). Despite land use differences and the greater influx of nutrients into the south compared to the north basin, the water in the south and north basins are similarly $\mathrm{pH}$ neutral (7.0 and 6.9, respectively; Best and Traill, 1994).

The climate at Loch Lomond is cool, windy and wet; the nearby Paisley weather station (ca. $40 \mathrm{~km}$ south from Loch Lomond (32 $\mathrm{m}$ a.s.l.) measures a mean annual air temperature (MAAT) of $9.5^{\circ} \mathrm{C}(1980-2010$, Fig. 2a) and mean annual precipitation of $1240 \mathrm{~mm} \mathrm{yr}^{-1}$ (1980-2010, Fig. 2a). Maximum temperatures generally occur in July $\left(15.9^{\circ} \mathrm{C}\right)$ and minimum temperatures in December and January $\left(4.3{ }^{\circ} \mathrm{C}\right)$. Precipitation is highest in January $\left(146 \mathrm{~mm} \mathrm{month}^{-1}\right)$ and lowest in April $\left(62 \mathrm{~mm} \mathrm{month}^{-1}\right)$. However, it is important to understand that these climates can vary widely within the Loch Lomond catchment area, due to varying elevations and subclimates (Birse, 1971; Bayfield and Conroy, 1995). For example, annual rainfall varies from a minimum of $1372 \mathrm{~mm} \mathrm{yr}^{-1}$ in the south, at Ballindaloch, to a maximum of $3008 \mathrm{~mm} \mathrm{yr}^{-1}$ at Inveruglas in the north (Curran and Poodle, 1992). The annual average water temperatures (integrated throughout the water column) are $7.8{ }^{\circ} \mathrm{C}$ in the north basin and $10.3^{\circ} \mathrm{C}$ in the south (Mohamad Hamzah, 2012). From May onwards, Loch Lomond is progressively thermally stratified through the summer months, clearest in the north basin. In late autumn, this thermocline breaks down and the lake is fully mixed throughout the winter and early spring (Slack, 1957). 

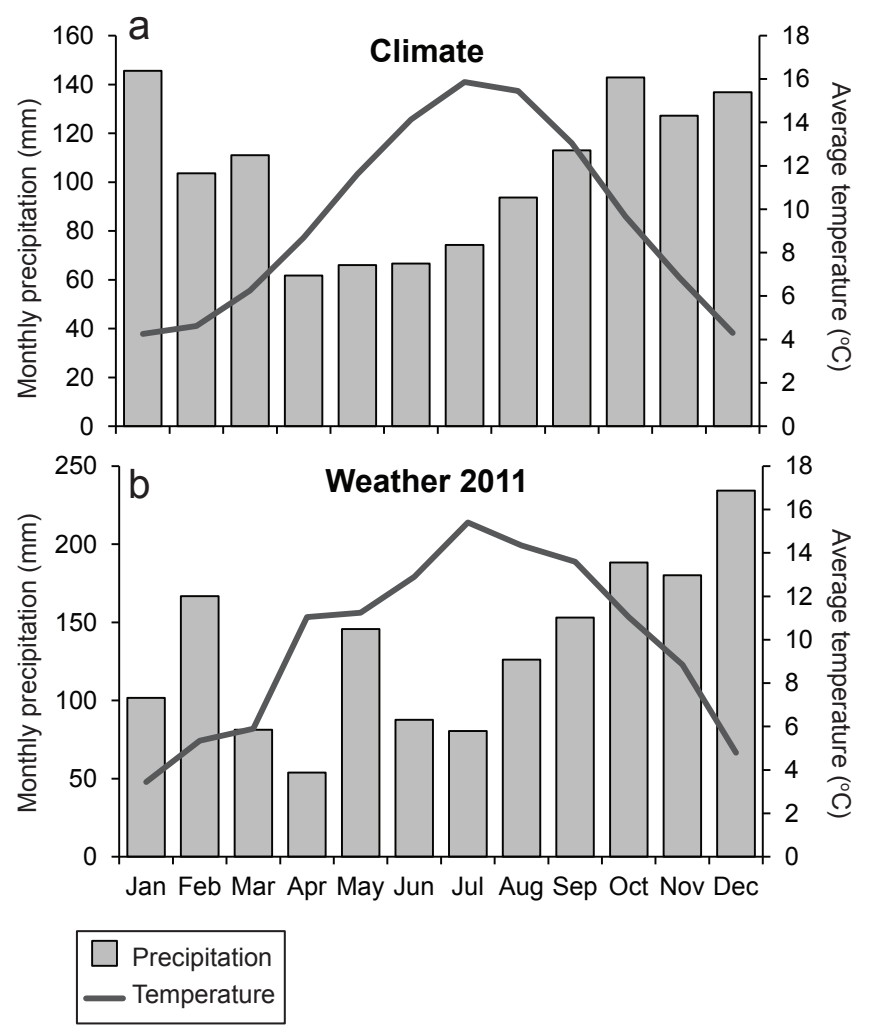

Figure 2. (a) Average monthly temperatures and precipitation for the years 1980-2010 and (b) mean monthly temperatures and precipitation for the year of SPM sampling, 2011, all recorded at the Paisley weather station, ca. $40 \mathrm{~km}$ from Loch Lomond and a $32 \mathrm{~m}$ elevation. All data are courtesy of the UK Met Office (http: //www.metoffice.gov.uk/climate/uk/stationdata/paisleydata.txt).

\subsection{Sampling}

Two sample campaigns were undertaken in March and September 2011 to collect catchment soils, catchment river and stream sediments and lake sediments. Nearly 2 years of settling particles (2005-2006) from the north and south basins were collected from the middle and bottom of the water columns. Suspended particulate matter (SPM) from rivers and streams, lake SPM and physicochemical depth profiles of the south, lower north and upper north basins were also analysed. Filtration of SPM took place in the onshore laboratories of SCENE within ca. $6 \mathrm{~h}$ of sampling; ca. $20 \mathrm{~L}$ of river water was filtered per sample through ashed glass fibre filters (Whatmann GF/F; pore size $0.7 \mu \mathrm{m}$ ). All samples were stored frozen until analysis.

\subsubsection{Soils}

Soils were sampled from within the catchment area of Loch Lomond, from a wide range of elevations ranging from lake level (ca. $8 \mathrm{~m}$ ) to ca. $180 \mathrm{~m}$ elevation to the north of the lake. The 13 soil samples were selected to cover a range of vege- tation and land use types occurring in the catchment around Loch Lomond. This includes peaty soils, grasslands, forests, fern-covered soils and two waterlogged soils. Grassland was often used to graze cattle. Wherever possible the soils were collected next to rivers/streams, in peaty soils on steep slopes and in areas of localised run-off, as those soils were considered most likely to contribute to GDGTs found in lake sediments. The large amount of water percolating through the soil may well carry clay particles with associated GDGTs to these streams. For sampling, any surface vegetation was removed and a ca. $10 \mathrm{~cm}$ depth interval of soil taken.

\subsubsection{Rivers}

Four riverine surface sediments and one overbank deposit were sampled (March and September 2011) from five different rivers and streams, all of which flow into Loch Lomond. With the exception of Endrick Water, all sediments consisted of medium to coarse sand, and the samples (ca. $0-5 \mathrm{~cm}$ depth) were taken with a trowel from the edge of an unnamed stream in Glen Luss (R6; Fig. 1), Douglas Water, Dubh Eas (a tributary of the River Falloch to the north-west) and below the Falls of Falloch (River Falloch), where the river water was less than $30 \mathrm{~cm}$ deep (see Fig. 1 for exact locations). The clay-silt overbank deposit (ca. $0-1 \mathrm{~cm}$ depth) was taken from Endrick Water.

SPM was sampled in surface water from Endrick Water in both March and September 2011. In September 2011, surface water SPM was also sampled from the River Falloch: once below the Falls of Falloch and once at the inflow to Loch Lomond in the north basin. River sediment was also collected at these locations.

\subsubsection{Lake}

In March, due to rough weather conditions, temperature and dissolved oxygen were measured ex situ with a Hanna HI 991300 portable $\mathrm{pH} /$ conductivity/dissolvedoxygen/temperature meter on water collected with a Van Dorn sampler in the south and lower north basin. In the south basin, these measurements were made on water sampled from $0,4,7,10$ and $14 \mathrm{~m}$ depth and in the lower north basin from 0 to $60 \mathrm{~m}$ depth at $10 \mathrm{~m}$ intervals. Water was taken in $20 \mathrm{~L}$ jerry cans and shipped to shore. In September, weather conditions allowed measurement of temperature, dissolved oxygen and $\mathrm{pH}$ of the full water column in the south, lower and upper north basins (Fig. 3b) using a TROLL 9522 water quality instrument. All measurements were taken at or as near as possible to the sediment traps in each basin (Fig. 1).

SPM depth profiles were sampled in both March and September 2011 in a north-south transect of Loch Lomond, using a Van Dorn sampler to bring up and collect up to $25 \mathrm{~L}$ of water per depth interval. Water was filtered through ashed glass fibre filters (Whatmann GF/F; pore size $0.7 \mu \mathrm{m}$ ) using a $20 \mathrm{~L}$ pressure tank connected to a Sartorious Stedim 


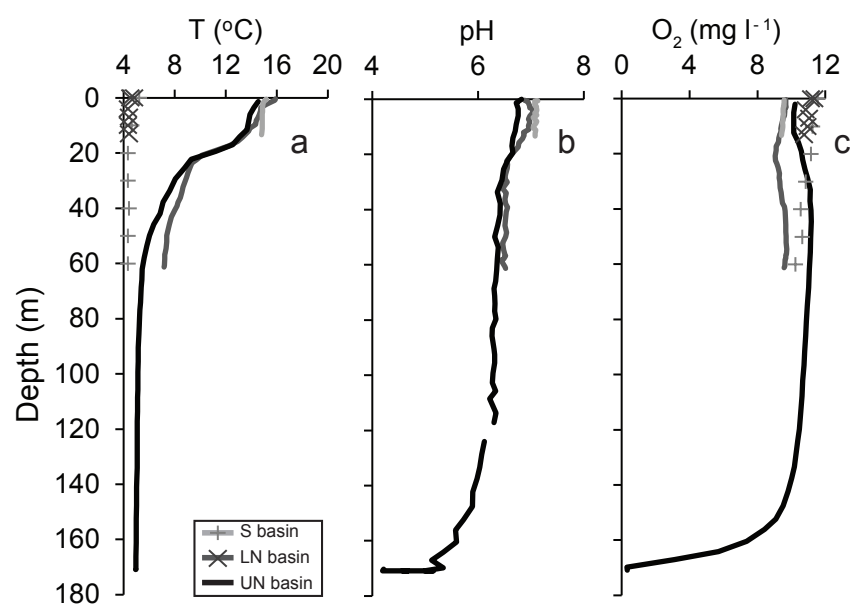

Figure 3. (a) Temperature, (b) $\mathrm{pH}$ and (c) dissolved-oxygen profiles measured in September 2011 from the south (S), lower north (LN) and upper north (UN) basins. Additional markers represent data from $\mathrm{S}$ and $\mathrm{LN}$ basins in March, measured ex situ.

filter apparatus; the filters were subsequently stored frozen. In March, bad weather conditions meant that SPM depth profiles could be sampled in the lower north basin and south basin only; in September, the full transect was sampled from the upper north to the south basin. In the south basin in March, SPM was sampled in the centre of the basin (ca. $14 \mathrm{~m}$ water depth) at five relatively regular intervals: $0,4,7,10$ and $13 \mathrm{~m}$ depth. In September, SPM was sampled from five regular intervals at $0,3,9$ and $12 \mathrm{~m}$ depth. SPM samples were taken from the centre of the lower north basin (water depth ca. $67 \mathrm{~m}$ ) from 0 to $60 \mathrm{~m}$ depth, at $10 \mathrm{~m}$ intervals, in both March and September. In September, water was sampled from the upper north basin between 0 and $80 \mathrm{~m}$ depth at $20 \mathrm{~m}$ intervals. The water depth was estimated at $180 \mathrm{~m}$ based on bathymetry; however, equipment did not allow samples to be taken from that depth.

Sediment traps were deployed in the south and middle basins from 13 May 2005 and collected on average every 45 days (between 25 and 63 days) until 8 March 2006, covering 267 days of settling particles. The locations of the two sediment traps are indicated in Fig. 1, at the locations of sediments P1 and P5. Upon collection, the material was stored in a cool box post-collection and refrigerated immediately upon return to shore $(<6 \mathrm{~h})$. Excess water was removed by centrifugation, and the resulting material was freeze-dried and stored frozen until analysis.

Lake surface sediments were collected in a north-south transect of Loch Lomond, covering a water depth range of 3-70 m (Fig. 1). Samples were collected using an Eckman grab, with an approximate depth range of $0-10 \mathrm{~cm}$. Sediments were stored frozen until analysis.

\subsection{GDGT analysis}

All soils, sediments, settling particles and GF/F filters were freeze-dried. Large stones and plant matter were removed from soil samples, and between 3 and $12 \mathrm{~g}$ were extracted by means of a modified Bligh-Dyer procedure (cf. Pitcher et al., 2011b). Between 11 and $34 \mathrm{~g}$ of each river sediment and between 3 and $9 \mathrm{~g}$ of each lake sediment were also extracted, as well as ca. $0.1 \mathrm{~g}$ of each sample of settling particles. In addition, half of each GF/F filter of lake or river SPM was cut up into small pieces and extracted. Each sample was ultrasonically extracted three times with a solvent mixture of methanol $(\mathrm{MeOH})$ : dichloromethane $(\mathrm{DCM})$ : phosphate buffer at $\mathrm{pH} 7.4$ in the ratio $10: 5: 4(v: v: v)$. Following each extraction, the supernatant was removed and collected; subsequently, through the addition of phosphate buffer and DCM, phase separation was initiated by altering the solvent mixture of $\mathrm{MeOH}: \mathrm{DCM}$ : phosphate buffer to a ratio of $10: 10: 9(v: v: v)$. The aqueous phase that resulted was extracted with DCM three times, and the extract from this procedure was collected. This was rotary-evaporated until nearly dry and filtered through pre-extracted cotton wool into a preweighed vial. Half or $25 \%$ of each of these Bligh-Dyer extracts (dependent on the mass of the extract) was separated over a silica gel stationary phase through column chromatography. The Bligh-Dyer extract was loaded onto the column using hexane : ethyl acetate $(1: 1, v: v)$, and the first fraction (CL) was eluted with $5 \mathrm{~mL}$ of this solvent. After the collection of the first fraction and prior to the elution of the second fraction (IPL), the Bligh-Dyer extract was washed with the second eluent and loaded onto the column. The second fraction was then eluted with $5 \mathrm{~mL} \mathrm{MeOH}$. Internal standard ( $\mathrm{C}_{46}$ glycerol trialkyl glycerol tetraether; GTGT) was added to each fraction to allow quantification (Huguet et al., 2006), and the fractions were dried under a flow of nitrogen gas. Of each IPL fraction, $10 \%$ was removed and analysed as CL fractions to determine the efficacy of the column separation. The remaining $90 \%$ was refluxed in $1.5 \mathrm{~N} \mathrm{HCl} / \mathrm{MeOH}$ solution for $2 \mathrm{~h}$ at $80^{\circ} \mathrm{C}$, followed by an aqueous workup where the $\mathrm{pH}$ of the mixture was increased to $\mathrm{pH} 4-5$ and extracted three times with DCM. This extract was then passed through anhydrous $\mathrm{Na}_{2} \mathrm{SO}_{4}$ columns to remove any remaining water and dried under nitrogen. This resulted in the acid hydrolysis of the IPL fraction, cleaving the polar head groups from the IPLs to form their CL derivatives and allowing analysis as CLs.

The CL, IPL and hydrolysed IPL fractions were dissolved in hexane:isopropanol $99: 1(v: v)$ and filtered through polytetrafluoroethylene (PTFE) $0.45 \mu \mathrm{m}$ filters prior to analysis by high-performance liquid chromatographyatmospheric pressure chemical ionisation/mass spectrometry (HPLC-APCI/MS). This was performed on an $\mathrm{Ag}$ ilent 1100 series HPLC connected to a Hewlett-Packard (HP) 1100 MSD SL mass spectrometer after the method of Schouten et al. (2007). GDGTs were quantified through 
selected ion monitoring (SIM) detection of their $[\mathrm{M}+\mathrm{H}]^{+}$ ions and through the use of HP Chemstation software. Differences in ionisation efficiencies were compensated for by the regular running of a standard mixture of crenarchaeol and the $\mathrm{C}_{46}$ GTGT (Huguet et al., 2006).

GDGT distributions were quantified using the following indices (see Fig. A1 for GDGT structures and nomenclature):

- The branched vs. isoprenoidal tetratether (BIT) index as defined by Hopmans et al. (2004):

$$
\text { BITindex }=\frac{[\mathrm{VI}]+[\mathrm{VII}]+[\mathrm{VIII}]}{[\mathrm{VI}]+[\mathrm{VII}]+[\mathrm{VIII}]+[\mathrm{V}]} ;
$$

- The MBT' as defined by Peterse et al. (2012), a slightly modified form of the original MBT index by Weijers et al. (2007) in which brGDGTs VIIIb and VIIIc are omitted:

$$
\mathrm{MBT}^{\prime}=\frac{[\mathrm{VI}]+[\mathrm{VIb}]+[\mathrm{VIc}]}{[\mathrm{VI}]+[\mathrm{VIb}]+[\mathrm{VIc}]+[\mathrm{VII}]+[\mathrm{VIIb}]+[\mathrm{VIIc}]+[\mathrm{VIII}]} ;
$$

- The degree of cyclisation (DC) as defined by Sinninghe Damsté et al. (2009):

$$
\mathrm{DC}=\frac{[\mathrm{VIb}]+[\mathrm{VIIb}]}{[\mathrm{VI}]+[\mathrm{VIb}]+[\mathrm{VII}]+[\mathrm{VIIb}]} ;
$$

- The cyclisation ratio of branched tetraethers (CBT) as defined by Weijers et al. (2007a):

$$
\mathrm{CBT}=-\log _{10}\left(\frac{[\mathrm{VIb}]+[\mathrm{VIIb}]}{[\mathrm{VI}]+[\mathrm{VII}]}\right)
$$

- and the TEX T6 $_{86}$ as defined by Schouten et al. (2002):

$$
\mathrm{TEX}_{86}=\frac{[\mathrm{III}]+[\mathrm{IV}]+\left[\mathrm{V}^{\prime}\right]}{[\mathrm{II}]+[\mathrm{III}]+[\mathrm{IV}]+\left[\mathrm{V}^{\prime}\right]} .
$$

The fractional abundance of each individual brGDGT is expressed as

$f[$ GDGTi $]=\frac{[\text { brGDGTi }]}{[\Sigma \text { brGDGTs }]}$,

where $f$ [brGDGT $i]$ represents fractional abundance of an individual brGDGT, [brGDGT $i$ ] represents concentration of the individual brGDGT and [ $\Sigma$ brGDGTs] represents the summed concentration of GDGTs VI(b, c)-VIII(b, c).

The proportion of IPL compared to CL GDGTs is expressed using \%IPL, defined as

$\% \mathrm{IPL}=\left(\frac{[\mathrm{IPL}]}{[\mathrm{IPL}]+[\mathrm{CL}]}\right) \times 100$

where [IPL] represents intact polar lipid concentration and $[C L]$ represents core lipid concentration.
$\mathrm{pH}$ estimates were calculated using the soil calibration by Peterse et al. (2012) (Peterse12):

$\mathrm{pH}=7.90-1.97 \mathrm{CBT}$.

MAAT estimates were also calculated using the Peterse et al. (2012) soil calibration:

MAAT $=0.81-5.67 \mathrm{CBT}+31.0 \mathrm{MBT}^{\prime}$.

Mean summer air temperature (MSAT) estimates were calculated using the lacustrine calibration by Pearson et al. (2011):

$\operatorname{MSAT}=20.9+(98.1 \times f[\mathrm{VIb}])-(12 \times f[\mathrm{VII}])$

$-(20.5 \times f[\mathrm{VIII}])$.

TEX $_{86}$ lake surface temperature (LST) estimates were calculated using the lacustrine calibration by Powers et al. (2010):

$\mathrm{LST}=-14.0+\left(55.2 \times \mathrm{TEX}_{86}\right)$.

$\mathrm{TEX}_{86}$ and MBT calibrations subsequently described in the text are denoted by the first author and year of the publication in which they were first proposed; for example, the MBTCBT lacustrine calibration described by Pearson et al. (2011) is referred to as Pearson11.

\subsection{Statistical analyses}

A MANOVA (multivariate analysis of variance) statistical analysis was performed using the $\mathrm{R}$ statistical computing programme, available from www.r-project.org, on brGDGT distributions from each sample group, i.e. on the fractional abundances of each brGDGT. Outliers were not removed since they were scrutinised and considered to represent the accurate data of unusual samples rather than errors in computation or analysis; however, CL and IPL GDGT VIIIb and VIIIc were excluded from the analysis due to their low abundance and zero-inflated values. For individual comparison, the MANOVA analysis was followed by Tukey's HSD (honestly significant difference) procedure for each univariate set of data for which the null hypothesis was rejected, in order to generate multiple comparisons for each GDGT between sample groups. A $90 \%$ confidence level was selected due to the relatively high analytical error in lower abundance samples, particularly for IPL GDGTs.

Pearson product-moment correlation coefficients $(r)$ were calculated using IBM SPSS Statistics 21, using two-tailed test of significance and bootstrapping at the $90 \%$ confidence interval. Following general guidelines, the strength of association is considered to be weak if $r$ is less than $(-) 0.3$, moderate from $(-) 0.3$ to less than $(-) 0.5$ and strong from $(-) 0.5$ upwards. 
Table 1. Locations and provenance of soils, in conjunction with crenarchaeol concentrations and summed brGDGT concentrations, BIT indices, $\mathrm{MBT}^{\prime}$ indices, $\mathrm{CBT}$ ratios, inferred $\mathrm{pH}$ and inferred mean annual air temperatures (MAATs).

\begin{tabular}{|c|c|c|c|c|c|c|c|c|c|c|c|c|c|c|c|c|c|c|c|c|c|}
\hline \multirow[t]{2}{*}{ Sample } & \multirow{2}{*}{$\begin{array}{l}\text { Basin } \\
\text { catch- } \\
\text { ment }^{\text {a }}\end{array}$} & \multirow[t]{2}{*}{ Provenance } & \multicolumn{4}{|c|}{ OS coordinates ${ }^{\mathrm{b}}$} & \multicolumn{2}{|c|}{$\begin{array}{c}\text { [Crenarchaeol] } \\
\text { (ng g }{ }^{-1} \text { dry wt.) }\end{array}$} & \multicolumn{2}{|c|}{$\begin{array}{c}\Sigma[\text { brGDGTs }] \\
\text { (ng g }{ }^{-1} \text { dry wt.) }\end{array}$} & \multirow[t]{2}{*}{$\begin{array}{l}\% \text { IPL } \\
\text { brGDGT }\end{array}$} & \multicolumn{2}{|c|}{ BIT } & \multicolumn{2}{|c|}{$\mathrm{MBT}^{\prime}$} & \multicolumn{2}{|c|}{ CBT } & \multicolumn{2}{|c|}{$\mathrm{pH}$} & \multicolumn{2}{|c|}{$\begin{array}{l}\text { MAAT - } \\
\text { soil }\left({ }^{\circ} \mathrm{C}\right)^{\mathrm{d}}\end{array}$} \\
\hline & & & & & & & IPL & $\mathrm{CL}$ & IPL & $\mathrm{CL}$ & & IPL & $\mathrm{CL}$ & IPL & $\mathrm{CL}$ & IPL & $\mathrm{CL}$ & IPL & $\mathrm{CL}$ & IPL & CL \\
\hline S1 & $\mathrm{S}$ & $\begin{array}{l}\text { Grass; water- } \\
\text { logged }\end{array}$ & BNG & 44494 & NS & 87661 & 2 & 4 & 23 & 413 & 5 & 0.90 & 0.99 & 0.38 & 0.40 & 1.11 & 1.24 & 5.8 & 5.5 & 6.3 & 6.2 \\
\hline S2 & $\mathrm{S}$ & $\begin{array}{l}\text { Forested; En- } \\
\text { drick Water. }\end{array}$ & BNG & 44894 & NS & 88425 & n.m. ${ }^{c}$ & 12 & n.m. & 904 & - & - & 0.99 & - & 0.42 & - & 1.04 & - & 6.0 & - & 7.9 \\
\hline S3 & $\mathrm{S}$ & $\begin{array}{l}\text { Grass; } \text { grazed } \\
\text { (cattle) }\end{array}$ & BNG & 50111 & NS & 82767 & 0 & 1 & 14 & 636 & 2 & 1.00 & 1.00 & 0.43 & 0.50 & 1.14 & 1.17 & 5.8 & 5.7 & 7.7 & 9.8 \\
\hline S4 & $\mathrm{S}$ & $\begin{array}{l}\text { Grass; } \text { grazed } \\
\text { (sheep) }\end{array}$ & $\mathrm{BNG}$ & 48652 & NS & 85383 & 1 & 16 & 75 & 637 & 10 & 0.98 & 0.97 & 0.44 & 0.39 & 0.95 & 1.05 & 6.3 & 6.0 & 9.2 & 6.8 \\
\hline S5 & $\mathrm{N}$ & Forested; peaty & BNG & 38200 & NS & 95957 & 28 & 28 & 193 & 574 & 25 & 0.87 & 0.95 & 0.34 & 0.46 & 1.40 & 1.32 & 5.1 & 5.3 & 3.5 & 7.5 \\
\hline S6 & $\mathrm{N}$ & Ferns & BNG & 35751 & NS & 93210 & 0 & 6 & 51 & 1179 & 4 & 0.99 & 0.99 & 0.43 & 0.44 & 0.92 & 1.01 & 6.4 & 6.1 & 8.9 & 8.7 \\
\hline S7 & $\mathrm{N}$ & Ferns & BNG & 34222 & NS & 97900 & 15 & 40 & 263 & 882 & 23 & 0.94 & 0.95 & 0.41 & 0.52 & 1.45 & 1.34 & 4.9 & 5.2 & 5.2 & 9.4 \\
\hline S8 & $\mathrm{N}$ & Forested; peaty & BNG & 36258 & NS & 99232 & 161 & 369 & 396 & 3246 & 11 & 0.70 & 0.89 & 0.38 & 0.44 & 1.31 & 1.35 & 5.3 & 5.2 & 5.1 & 6.8 \\
\hline S9 & $\mathrm{N}$ & Forested; peaty & $\mathrm{BNG}$ & 36287 & NS & 99196 & 14 & 58 & 800 & 7600 & 9 & 0.98 & 0.99 & 0.45 & 0.61 & 1.38 & 1.45 & 5.1 & 4.9 & 7.0 & 11.4 \\
\hline $\mathrm{S} 10$ & $\mathrm{~N}$ & $\begin{array}{l}\text { Reeds; water- } \\
\text { logged. }\end{array}$ & BNG & 31729 & NN & 16232 & 31 & 80 & 998 & 6934 & 13 & 0.96 & 0.99 & 0.45 & 0.39 & 0.68 & 0.99 & 7.0 & 6.1 & 11.0 & 7.3 \\
\hline S11 & $\mathrm{N}$ & Peaty & BNG & 31738 & $\mathrm{NN}$ & 19956 & 2 & 2 & 255 & 1788 & 12 & 0.99 & 1.00 & 0.39 & 0.47 & 1.31 & 1.67 & 5.3 & 4.4 & 5.6 & 6.0 \\
\hline $\mathrm{S} 12$ & $\mathrm{~N}$ & $\begin{array}{l}\text { Peaty/clay; } \\
\text { grazed (sheep) }\end{array}$ & $\mathrm{BNG}$ & 35290 & $\mathrm{NN}$ & 21669 & 4 & 1 & 54 & 682 & 7 & 0.93 & 1.00 & 0.39 & 0.42 & 1.17 & 1.25 & 5.7 & 5.5 & 6.1 & 6.9 \\
\hline S13 & $\mathrm{N}$ & $\begin{array}{l}\text { Peaty/clay; } \\
\text { grazed (sheep) }\end{array}$ & BNG & 35349 & $\mathrm{NN}$ & 21684 & 0 & 0 & 300 & 3464 & 8 & 1.00 & 1.00 & 0.58 & 0.62 & 1.43 & 1.50 & 5.0 & 4.8 & 10.6 & 11.7 \\
\hline
\end{tabular}

${ }^{\mathrm{a}} \mathrm{S}$ - south catchment, $\mathrm{N}$ - north catchment, ${ }^{\mathrm{b}}$ Ordnance Survey coordinates, ${ }^{\mathrm{c}}$ n.m. - not measured, ${ }^{\mathrm{d}}$ Peterse12 calibration (Eq. 9).

\section{Results}

\subsection{Soils}

The soils are heterogeneous in nature, showing considerable variation in GDGT concentrations and distributions (Table 1). CL concentrations of brGDGTs range over an order of magnitude from 0.4 to $7.6 \mu \mathrm{g} \mathrm{g}^{-1}$ dry weight soil, and IPL brGDGTs concentrations are lower, ranging by 2 orders of magnitude from 0.01 to $1.0 \mathrm{\mu g} \mathrm{g}^{-1}$ dry weight soil. The \%IPL of the brGDGTs, representing the proportion of IPL "living" vs. CL 'fossil' GDGTs, ranges from 2 to $25 \%$ but does not appear to be related to the type of soil. Generally, peaty soils contain the highest concentrations of brGDGTs. Crenarchaeol concentrations are universally low, ranging from $<0.05 \mu \mathrm{g} \mathrm{g}^{-1}$ dry weight soil (CL and IPL) to maxima of 0.2 and $0.4 \mu \mathrm{g} \mathrm{g}^{-1}$ dry weight soil (IPL and CL, respectively).

BIT indices are universally high (Table 1). CL BIT indices do not reach below 0.95, and IPL BIT indices generally not reach below 0.90 , with one notable exception: S8 shows BIT indices of 0.89 and 0.70 for CL and IPL, respectively. BrGDGT distributions show some scatter, as is evident from a provenance plot of MBT' vs. DC (Fig. 4a, b). In this plot DC values (linearly related to the number of cyclopentane moieties of brGDGTs) are plotted in lieu of (logarithmic) CBT because the parameter for degree of methylation, MBT', is also linearly related. BrGDGT distributions are similar in IPL and CL brGDGTs (Fig. 5a, b). Both IPL and CL MBT' and DC/CBT indices range substantially. The lowest MBT' indices are 0.34 and 0.39 (IPL and CL, respectively), and the highest are 0.58 and 0.62 (IPL and CL). CBT indices vary from 0.68 to 1.45 (IPL) and from 0.99 to 1.67 (CL). IPL and CL MBT' values in soils are relatively weakly correlated $\left(r^{2}=0.34\right)$, although IPL and CL CBT values are more highly correlated $\left(r^{2}=0.69\right)$. The soil with lowest CL and IPL CBT values originates from a waterlogged river bank.

\subsection{River}

\subsubsection{SPM}

Concentrations of IPL and CL brGDGTs in SPM filtered from the surface waters of the River Falloch in the north catchment of Loch Lomond are constant at the Falls of Falloch and the mouth of the river at ca. $6 \mathrm{ng} \mathrm{L}^{-1}$ (IPL) and ca. $65 \mathrm{ng} \mathrm{L}^{-1}$ (CL) (Table 2). Concentrations of IPL and CL brGDGTs in Endrick Water in the south catchment were in September (IPL: 11; CL: $117 \mathrm{ng} \mathrm{L}^{-1}$ ) higher than double those in March (IPL: 4; CL: $51 \mathrm{ng} \mathrm{L}^{-1}$ ). The \%IPL of brGDGTs ranges between 7 and $9 \%$ for all river SPM. Crenarchaeol concentrations are generally low; IPL crenarchaeol is $<1 \mathrm{ng} \mathrm{L}^{-1}$, and CL crenarchaeol is $<2 \mathrm{ng} \mathrm{L}^{-1}$ (Table 2).

BIT indices are generally high at $0.94-0.99$ (IPL) and 0.98-0.99 (CL) (Table 2). BrGDGT distributions are similar in IPL and CL brGDGTs (Fig. 5c, d), and the variation in MBT' and DC/CBT is, consequently, relatively small (Fig. 4a, b). Reflecting this, MBT' values are similar in IPL and CL brGDGTs, ranging from 0.37 to 0.43 (IPL) and 0.37 to 0.39 (CL). However, CBT values of SPM from Endrick Water in the south (IPL: 0.97; CL: 1.08) are notably different to values of SPM from the River Falloch in the north (IPL: 1.28; CL: 1.41). IPL CBT of river SPM is always slightly lower than the CL CBT. 
Table 2. Suspended particulate matter (SPM) from river and lake water: crenarchaeol and summed brGDGT concentrations, MBT' indices, CBT ratios, BIT indices, TEX $_{86}$ indices, inferred mean annual air temperatures (MAATs), inferred mean summer air temperatures (MSATs) and inferred lake surface temperatures (LSTs).

\begin{tabular}{|c|c|c|c|c|c|c|c|c|c|c|c|c|c|c|c|c|c|c|c|c|c|c|c|c|c|c|c|c|}
\hline \multirow[t]{2}{*}{$\begin{array}{l}\text { Sample } \\
\text { name }\end{array}$} & \multirow[t]{2}{*}{$\begin{array}{l}\text { SPM } \\
\text { type }\end{array}$} & \multirow[t]{2}{*}{ Basin $^{\mathrm{a}}$} & \multirow{2}{*}{\multicolumn{4}{|c|}{ OS coordinates ${ }^{\mathrm{b}}$}} & \multirow{2}{*}{$\begin{array}{l}\text { Water } \\
\text { depth } \\
\text { (m) }\end{array}$} & \multirow[t]{2}{*}{ Month } & \multirow{2}{*}{$\begin{array}{l}\text { Depth } \\
\text { (m) }\end{array}$} & \multicolumn{2}{|c|}{$\begin{array}{c}\text { [Crenarchaeol] } \\
\left(\mathrm{ng} \mathrm{L}^{-1}\right)\end{array}$} & \multicolumn{2}{|c|}{$\begin{array}{c}\Sigma[\text { brGDGTs }] \\
\left(\mathrm{ngL}^{-1}\right)\end{array}$} & \multirow[t]{2}{*}{$\begin{array}{l}\% \text { IPL } \\
\text { brGDGT }\end{array}$} & \multicolumn{2}{|c|}{ BIT } & \multicolumn{2}{|c|}{$\mathrm{MBT}^{\prime}$} & \multicolumn{2}{|c|}{ CBT } & \multicolumn{2}{|c|}{$\begin{array}{l}\text { MAAT - } \\
\text { soil }\left({ }^{\circ} \mathrm{C}\right)^{\mathrm{c}}\end{array}$} & \multicolumn{2}{|c|}{$\begin{array}{c}\text { MSAT - } \\
\text { lake }\left({ }^{\circ} \mathrm{C}\right)^{\mathrm{d}}\end{array}$} & \multicolumn{2}{|c|}{ TEX $_{86 f}$} & \multicolumn{2}{|c|}{$\operatorname{LST}\left({ }^{\circ} \mathrm{C}\right)^{\mathrm{e}}$} \\
\hline & & & & & & & & & & IPL & $\mathrm{CL}$ & IPL & $\mathrm{CL}$ & & IPL & $\mathrm{CL}$ & IPL & $\mathrm{CL}$ & IPL & $\mathrm{CL}$ & IPL & $\mathrm{CL}$ & IPL & CL & IPL & $\mathrm{CL}$ & IPL & $\mathrm{CL}$ \\
\hline R1 & River & $\mathrm{S}$ & BNG & 44894 & NS & 88425 & 2 & Mar & 0 & 0.2 & 1.1 & 3.8 & 50.7 & 0.94 & 0.98 & 0.37 & 0.37 & 0.97 & 1.05 & 6. & 6.2 & 17.1 & 16.0 & n.c. ${ }^{f}$ & c. & .c. & c. & \\
\hline R2 & River & $\mathrm{s}$ & BNG & 44894 & NS & 88425 & 2 & Sep & 0 & 0.7 & 1.9 & 11.4 & 117 & 9 & 0.94 & 0.98 & 0.38 & 0.38 & 0.97 & 1.08 & 7.1 & 6.3 & 17.4 & 16.0 & n.c. & n.c. & n.c. & n.c. \\
\hline R3 & River & UN & BNG & 31729 & NN & 16232 & 1 & Sep & 0 & 0.1 & 0.6 & 6.4 & 69.3 & 8 & 0.99 & 0.99 & 0.43 & 0.39 & 1.36 & 1.41 & 6.4 & 5.0 & 15.4 & 14.5 & n.c. & n.c. & n.c. & n.c. \\
\hline R4 & River & UN & BNG & 33495 & NN & 20762 & $<0.5$ & Sep & 0 & 0.2 & 0.6 & 5.7 & 62.7 & 8 & 0.97 & 0.99 & 0.39 & 0.39 & 1.21 & 1.41 & 6.0 & 5.0 & 15.4 & 14.3 & n.c. & n.c. & n.c. & n.c. \\
\hline LL2f & Lake & $\mathrm{S}$ & BNG & 38315 & NS & 90165 & 15.4 & Mar & 0 & 0.1 & 1.0 & 1.1 & 9.0 & 11 & 0.87 & 0.90 & 0.39 & 0.39 & 1.03 & 1.19 & 6.9 & 6.1 & 16.6 & 15.4 & 0.58 & 0.51 & 17.9 & 14.3 \\
\hline LL3f & Lake & $\mathrm{s}$ & BNG & 38315 & NS & 90165 & 15.4 & Mar & 4 & & 1.1 & 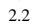 & 11.1 & 17 & 0.87 & 0.91 & 0.37 & 0.40 & 1.00 & 1.21 & 6.5 & 6.3 & 16.5 & 15.3 & 0.58 & 0.52 & 17.8 & 14.4 \\
\hline LL4f & Lake & $\mathrm{s}$ & BNG & 38315 & NS & 90165 & 15.4 & Mar & 7 & 0.1 & 0.9 & 0.8 & 11.3 & 6 & 0.87 & 0.92 & 0.42 & 0.40 & 1.05 & 1.17 & 7.8 & 6.7 & 16.9 & 15.7 & 0.56 & 0.52 & 17.0 & 14.5 \\
\hline LL5f & Lake & $\mathrm{s}$ & BNG & 38315 & NS & 90165 & 15.4 & Mar & 10 & 0.1 & 1.1 & 1.4 & 11.6 & 11 & 0.89 & 0.91 & 0.38 & 0.40 & 1.03 & 1.18 & 6.6 & 6.6 & 16.5 & 15.7 & 0.58 & 0.51 & 18.3 & 13.9 \\
\hline LL6f & Lake & $\mathrm{s}$ & BNG & 38315 & NS & 90165 & 15.4 & Mar & 13 & 0.2 & 1.0 & 1.1 & 10.4 & 10 & 0.87 & 0.91 & 0.37 & 0.40 & 1.02 & 1.17 & 6.4 & 6.5 & 16.1 & 15.7 & 0.57 & 0.51 & 17.6 & 14.0 \\
\hline LW14 & Lake & $\mathrm{S}$ & NG & 38315 & NS & 90165 & 12.4 & Sep & 0 & 0.0 & 0.2 & 0.8 & 6.6 & 11 & 0.94 & 0.96 & 0.36 & 0.42 & 1.00 & 1.14 & 6.4 & 7.5 & 16.1 & 16.1 & 0.55 & 0.53 & 16.5 & 15.3 \\
\hline LW15 & Lake & $\mathrm{s}$ & BNG & 38315 & NS & 90165 & 12.4 & Sc & & & 1. & 0.4 & 5. & o & 86 & 0.84 & 0.38 & 0.39 & 1.26 & 1.34 & 5.5 & 5.4 & 14.7 & 14.4 & 0.53 & 0.45 & 15.5 & 10.8 \\
\hline LW16 & & $\mathrm{S}$ & & 38 & NS & 9 & 1 & Se & 6 & & 0. & & 4 & 10 & & 0.96 & 0.37 & 0.41 & 1.01 & 1.13 & 6.5 & & 15.8 & 15.9 & 0.56 & & .0 & 14.6 \\
\hline LW17 & Lake & S & BNG & 38315 & NS & 90165 & 12.4 & Sep & & & 0.2 & 0.7 & 4.9 & 13 & 0.95 & 0.96 & 0.39 & 0.41 & 1.02 & 1.12 & 7.1 & 7.3 & 16.7 & 16.0 & 0.55 & 0.50 & 16.3 & 13.6 \\
\hline LW18 & Lake & S & BNG & 38315 & NS & 90165 & 12.4 & Sep & 12 & 0.0 & 0.2 & 0.6 & 5.9 & 9 & 0.93 & 0.96 & 0.37 & 0.41 & 0.96 & 1.12 & 6.9 & 7.1 & 17.0 & 16.0 & 0.55 & 0.52 & 16.2 & 14.8 \\
\hline LL7f & Lake & LN & BNG & 36538 & NS & 94789 & 67.5 & Mar & 0 & 0.2 & 1. & 0.8 & 8. & 9 & 0.79 & 0.80 & 0.37 & 0.39 & 1.04 & 1.2 & 6.3 & 5.6 & 16.0 & 14.8 & 0.58 & 0.45 & 18.0 & 10.7 \\
\hline LL8f & & & & & $\mathrm{N}$ & 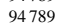 & & & & & & & & 8 & & & & 0.39 & & & & & 16.7 & 14.9 & & & & 0.1 \\
\hline LL9f & Lake & LN & BNG & 36538 & NS & 94789 & 67. & Uar & & & 1. & .9 & 7.8 & 10 & 0.74 & 0.80 & 0.37 & 0.39 & 1.03 & 1.29 & 6.5 & 5.6 & 16.4 & 14.8 & 0.55 & 0.45 & 16.5 & 10.6 \\
\hline LL10f & Lake & $\mathrm{LN}$ & BNG & 36538 & NS & 94789 & 67 & 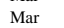 & & & 25 & 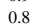 & 10.7 & 7 & 75 & 0.80 & 0.37 & 0.38 & 1.02 & 1.27 & 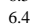 & 50 & 16.6 & 14.8 & 0.55 & 0.47 & 16.2 & 11.9 \\
\hline LL11f & Lake & LN & BNG & 36538 & NS & 94789 & 67. & M & 4 & 0 & 2. & 1.0 & 10 & Y & 0.76 & 0.77 & 0.38 & 0.38 & 1.09 & 1.25 & 6.5 & 5.5 & 15.4 & 14.8 & 0.55 & 0.46 & 16.1 & 11.4 \\
\hline LL12f & Lake & $\mathrm{LN}$ & G & 36538 & NS & 94789 & 67. & Mar & 0 & & 2.4 & 1 & 10 & 10 & .71 & 0.80 & 0.38 & 0.40 & 1.02 & 1.28 & 6.8 & 6.0 & 16.6 & 15.0 & 0.54 & 0.44 & 15.7 & 10.5 \\
\hline LL13f & Lake & LN & BNG & 36538 & NS & 94789 & 67.5 & Mar & 60 & 0.4 & 2.4 & 1.1 & 10.2 & 10 & 0.72 & 0.80 & 0.38 & 0.40 & 1.03 & 1.28 & 6.8 & 5.8 & 16.6 & 14.9 & 0.55 & 0.43 & 16.2 & 9.9 \\
\hline Jy & Lake & $\mathrm{LN}$ & BNG & 36538 & NS & 94789 & 66.4 & Sep & 0 & & 0.3 & 0.7 & 5.8 & 11 & 0.88 & 0.94 & & 0.43 & 114 & 1.30 & & 6.9 & 15.7 & 15.5 & 6 & 2 & 0 & .6 \\
\hline LW20 & Lake & LI & & 36538 & NS & 789 & & & 1 & & 0 & & 9 & 1 & & 0.92 & 0.35 & 0 & 1.17 & & 1 & 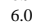 & 15.0 & 14.8 & 59 & 0.50 & 8.7 & 13.8 \\
\hline LW21 & Lake & $\mathrm{LN}$ & & 8 & NS & & 66 & $\mathrm{~s}$ & 2 & & 1. & & 6. & 1 & & 0.79 & 0.38 & 0.40 & 1.28 & 1.36 & 5.2 & 5. & 15.5 & 14.7 & 0.51 & 0.42 & 14.2 & 9.3 \\
\hline LW2 & Lake & LN & & 36538 & NS & & & & & 0. & 4. & & 7. & 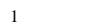 & & 0.60 & 0.36 & 0.39 & 1.09 & & & 5.3 & 15.2 & 14.3 & 0.44 & 38 & 0.3 & 7.1 \\
\hline & & LN & & & $\mathrm{N}$ & & & & & & 3 & & . & 11 & & & 037 & 0. & & & & 5 & 15.2 & 14.1 & & & .5 & 6.2 \\
\hline LW24 & Lake & LN & BNG & 36538 & NS & 94789 & 66.4 & Sep & 50 & 0.6 & 6.0 & 1.1 & 8.5 & 12 & 0.63 & 0.57 & 0.38 & 0.38 & 1.07 & 1.32 & 6.6 & 5.2 & 15.8 & 14.3 & 0.45 & 0.38 & 11.1 & 7.0 \\
\hline LW25 & Lake & LN & BNG & 36538 & NS & 94789 & 66.4 & Sep & 60 & 0.0 & 6.3 & 0.1 & 8.9 & 1 & 0.66 & 0.57 & 0.39 & 0.38 & 1.05 & 1.31 & 6.9 & 5.1 & 16.1 & 14.2 & 0.49 & 0.39 & 12.9 & 7.5 \\
\hline LL3. & $\mathrm{L}$ & U & BNG & 3 & $\mathrm{~N}$ & 06243 & 180 & Se & & 0 & 0. & 0. & 7. & 8 & t & 0.95 & 39 & 0.38 & 1.27 & 7 & 6 & 3.6 & 15.0 & 14.1 & 0.53 & 0.50 & 5.4 & 3.6 \\
\hline LL & & $\mathrm{U}$ & & & N & & & & & & & & & 10 & & & & & & & 1 & 7. & 15.7 & 16.0 & & & 5.9 & 16.2 \\
\hline LL35 & Lake & UN & BNG & 33618 & NN & 06243 & 180 & $\mathrm{Se}$ & 40 & 0.1 & 2. & 0. & 7. & 9 & 0.82 & 0.77 & 0.34 & 0.39 & 1.20 & 1.36 & 4.4 & 5.1 & 14.5 & 14.4 & 0.55 & 0.40 & 16.5 & 8.1 \\
\hline LL & Lak & $\mathrm{U}$ & & & $\mathrm{NI}$ & & 18 & & o & 0 & 1. & & 6. & r & & 0.76 & & & & & J & & & 14.2 & 49 & & 3.1 & 8.4 \\
\hline LL37 & Lake & UN & BNG & 33618 & NN & 06243 & 180 & Sep & 80 & 0.2 & 1.8 & 0.9 & 6.6 & 12 & 0.84 & 0.78 & 0.37 & 0.39 & 1.18 & 1.38 & 5.6 & 5.0 & 15.1 & 14.3 & 0.53 & 0.40 & 15.2 & 8.4 \\
\hline
\end{tabular}

${ }^{a} \mathrm{~S}$ - south, LN - , lower north, UN - upper north, ${ }^{b}$ Ordnance Survey coordinates, ${ }^{\mathrm{C}}$ Peterse12 calibration (Eq. 9), ${ }^{\mathrm{d}}$ Pearson11 calibration (Eq. 10), ${ }^{\mathrm{e}}$ Powers 11 calibration (Eq. 11), ${ }^{\mathrm{f}}$ n.c. - not calculated; TEX 86 values and lake surface temperature (LST) estimates are included where the CL BIT index $\leq 0.6$.

Table 3. River sediment data: crenarchaeol and summed brGDGT concentrations, BIT indices, MBT $^{\prime}$ indices, CBT ratios, inferred mean annual air temperatures (MAATs) and inferred mean summer air temperatures (MSATs).

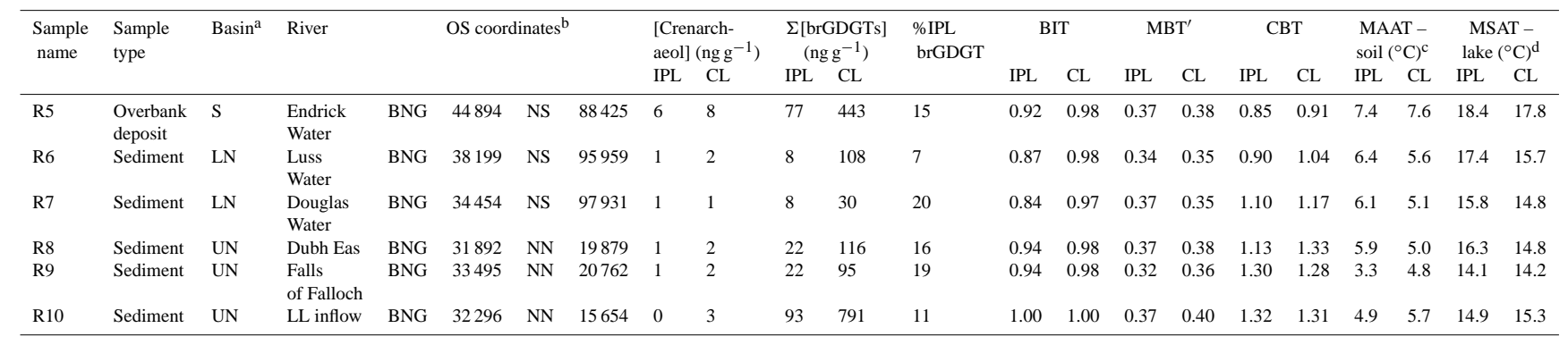

a $\mathrm{S}$ - south, LN - lower north, UN - upper north, ${ }^{\mathrm{b}}$ Ordnance Survey

coordinates, ${ }^{c}$ Peterse 12 calibration (Eq. 9), ${ }^{\mathrm{d}}$ Pearson 11 calibration (Eq. 10).

\subsubsection{Sediment}

River sediments contain 8 to $93 \mathrm{ng} \mathrm{g}^{-1}$ dry weight sediment IPL brGDGTs and 30 to $790 \mathrm{ng} \mathrm{g}^{-1}$ dry weight sediment CL brGDGTs (Table 3). The \%IPL of brGDGTs ranges between 7 and $19 \%$. Crenarchaeol concentrations are low for both IPLs ( 0 to $6 \mathrm{ng} \mathrm{g}^{-1}$ ) and CLs ( 1 to $\left.8 \mathrm{ng} \mathrm{g}^{-1}\right)$. BIT indices are generally higher in CL than IPL GDGTs, ranging from 0.84 to 1.00 (IPL) and 0.97 to 1.00 (CL). IPL and CL brGDGT distributions are similar (Fig. 5e, f), resulting in only small variations in MBT' and CBT/DC (Fig. 4a, b). MBT' values are similar between IPL and CL brGDGTs and between different river sediments, ranging from 0.32 to 0.37 (IPL) and
0.35 to 0.40 (CL) (Table 3). On the other hand, CBT ratios are lowest in River Endrick sediment in the south basin (IPL: 0.85; CL: 0.91), higher in rivers and streams flowing into the lower north basin (mean values of IPL: 1.00; CL: 1.11) and highest in rivers and streams flowing into the upper north basin (mean values of IPL: 1.25; CL: 1.31).

\subsection{Lake}

\subsubsection{Water column}

Temperature and dissolved oxygen profiles based on ex situ water samples taken from the south and lower north basins 

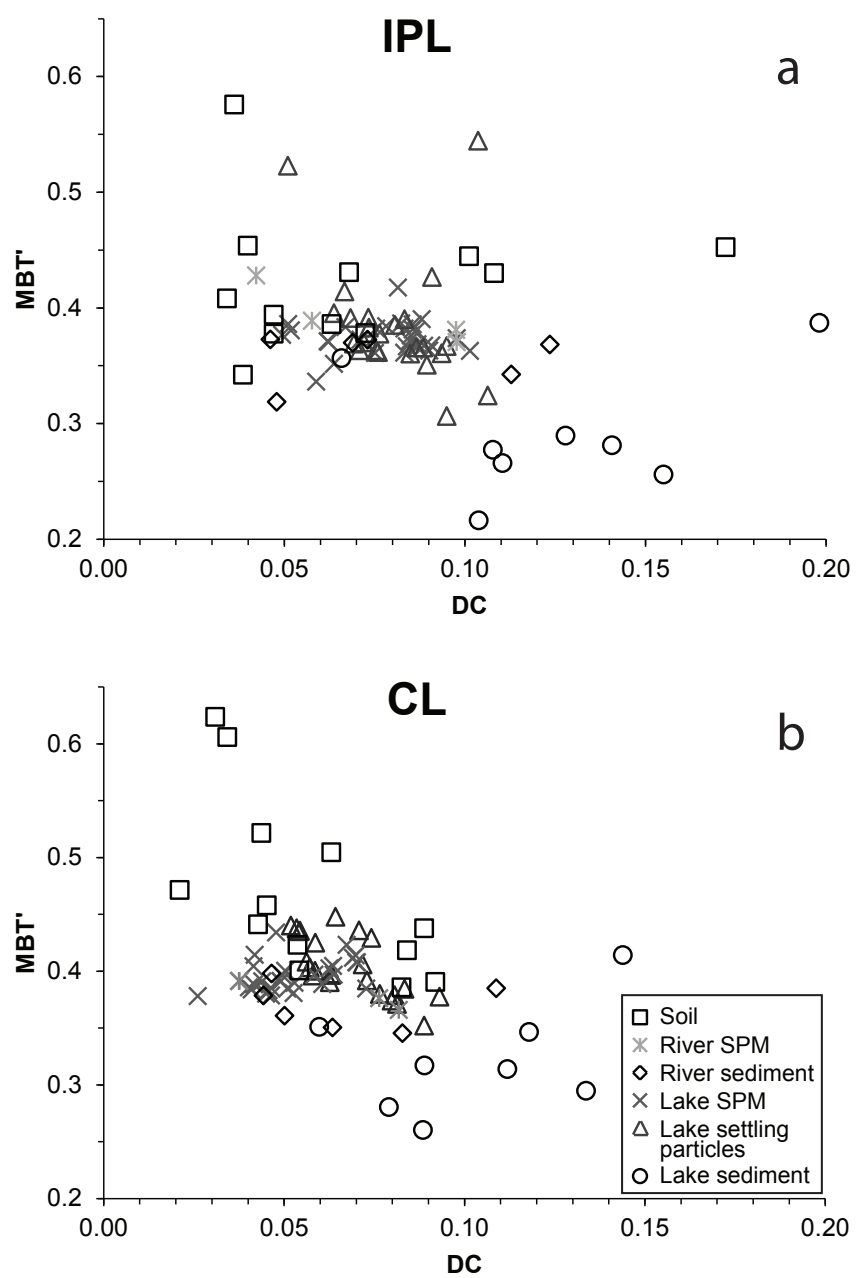

Figure 4. Cross-plots of MBT' vs. DC of (a) IPL and (b) CL brGDGT lipids showing the differences in distribution between the sample groups.

in March show a fully mixed water column (Fig. 3a). In the south basin, the full water column is at a temperature of ca. $4.5^{\circ} \mathrm{C}$. Dissolved-oxygen concentrations were found to be ca. $10.5 \mathrm{mg} \mathrm{L}^{-1}$ (Fig. 3c), meaning that the water column is fully oxygenated. The lower north basin shows slightly higher temperatures at the surface $\left(5.2^{\circ} \mathrm{C}\right)$ compared with average temperatures of $4.3^{\circ} \mathrm{C}$ at and below $20 \mathrm{~m}$ depth. However, this small difference does not represent a strong, seasonal thermocline. The water column is fully oxygenated with dissolved-oxygen concentrations of ca. $10.8 \mathrm{mg} \mathrm{L}^{-1}$. The year 2011 was reasonably average in terms of weather (Fig. 2b), so these conditions are likely representative of conditions in the water column during these months.

In September, the south basin is again fully mixed at a temperature of ca. $15^{\circ} \mathrm{C}$ (Fig. 3a). Dissolved-oxygen concentrations are also relatively constant, with an average of $9.5 \mathrm{mg} \mathrm{L}^{-1}$ (Fig. 3b), and the $\mathrm{pH}$ is relatively constant (7.0 to 7.1) throughout the water column (Fig. 3c). The lower north basin is thermally stratified in September with the ther- mocline at around $15 \mathrm{~m}$ depth; above the thermocline, water temperatures are around $14{ }^{\circ} \mathrm{C}$, and below the thermocline the water is at ca. $8^{\circ} \mathrm{C}$ (Fig. 3a). Dissolved oxygen is, however, relatively constant (ca. $9.5 \mathrm{mg} \mathrm{L}^{-1}$; Fig. 3b), meaning that the water column remains fully oxygenated. The $\mathrm{pH}$ gradient follows the thermocline (Fig. $3 \mathrm{c}$ ); the $\mathrm{pH}$ is ca. 7.0 above and ca. 6.5 below the thermocline. The upper north basin has a thermocline at ca. $20 \mathrm{~m}$ depth (Fig. 3a), where temperatures above the thermocline are ca. $14{ }^{\circ} \mathrm{C}$ and drop to ca. $5{ }^{\circ} \mathrm{C}$ in bottom waters. Dissolved-oxygen concentrations range from 9.4 to $10.7 \mathrm{mg} \mathrm{L}^{-1}$ down to $130 \mathrm{~m}$ depth (Fig. 3b), at which point concentrations begin to drop precipitously to reach near-zero values at the sediment $(171 \mathrm{~m}$ depth). The measured $\mathrm{pH}$ is ca. 6.7 at the surface and drops slowly to 6.3 (Fig. 3c). At around $115 \mathrm{~m}$ depth, the $\mathrm{pH}$ begins to further decrease to ca. 5.2 at around $170 \mathrm{~m}$ depth just above the sediment.

\subsubsection{SPM}

In the south basin, March brGDGT concentrations in lake SPM are relatively constant throughout the water column, varying from 0.8 to $2.2 \mathrm{ng} \mathrm{L}^{-1}$ (IPL) and 9.0 to $11.6 \mathrm{ng} \mathrm{L}^{-1}$ (CL; Table 2). In September, south basin brGDGT concentrations are similarly constant but are slightly lower, ranging from 0 to $1 \mathrm{ng} \mathrm{L}^{-1}$ (IPL) and 5 to $7 \mathrm{ng} \mathrm{L}^{-1}$ (CL). The $\%$ IPL of brGDGTs ranges between 6 and $17 \%$. Crenarchaeol concentrations are low in both March and September, at ca. $0.05 \mathrm{ng} \mathrm{L}^{-1}$ (IPL) and ranging from 0.2 to $1 \mathrm{ng} \mathrm{L}^{-1}$ (CL). IPL $\mathrm{TEX}_{86}$ indices are relatively constant, ranging from 0.56 to 0.58 and 0.53 to 0.55 in March and September, respectively. CL $\mathrm{TEX}_{86}$ indices are slightly lower but still relatively invariable with depth in March, ranging from 0.51 to 0.52 , but vary slightly more in September, from 0.45 to 0.53 . CL BIT indices are marginally lower in March compared with September (0.91 vs. 0.94, respectively, for CL); IPL BIT indices show the same trend though with slightly lower values (0.88 vs. 0.92 ; March and September, respectively). BrGDGT distributions do not vary widely with depth or season of sampling; MBT' values are quite constant for both March and September and for both IPL and CL brGDGTs, ranging between 0.36 and 0.42 in IPL and 0.39 and 0.42 in CL brGDGTs. CBT values derived from IPL brGDGTs are generally lower than those from CL brGDGTs, and the March and September profiles yield similar values, i.e. ca. 1.04 (IPL) and 1.17 (CL).

In the lower north basin, concentrations of both IPL and CL brGDGTs are generally also slightly higher in March (IPL: $1 \mathrm{ng} \mathrm{L}^{-1}$; CL: 8-14 $\mathrm{ng} \mathrm{L}^{-1}$ ) than in September (IPL: 0$1 \mathrm{ng} \mathrm{L}^{-1}$; CL: $5-9 \mathrm{ng} \mathrm{L}^{-1}$ ) (Table 2). The \% IPL of brGDGTs ranges between 1 and $12 \%$. Crenarchaeol concentrations in March are relatively evenly spread throughout the profile, with a small peak in abundance at $10 \mathrm{~m}$ depth in both IPLs $\left(1 \mathrm{ng} \mathrm{l}^{-1}\right)$ and CLs $\left(4 \mathrm{ng} \mathrm{L}^{-1}\right)$, but in September concentrations generally increase with depth to maxima of $1 \mathrm{ng} \mathrm{L^{-1 }}$ 



Figure 5. Bar plots (a-q) representing averaged IPL and CL brGDGT distributions in sample groups by basin and, in the case of settling particles, by the depth of collection. Errors are equal to $1 \sigma$. 
Table 4. Settling particles data from sediment trap deployments from 13 May 2005 to 8 March 2006 from the middle and bottom of the water column: crenarchaeol fluxes and brGDGT fluxes and BIT indices, MBT $^{\prime}$ indices, CBT ratios, TEX 86 indices, inferred mean annual air temperatures (MAATs), inferred mean summer air temperatures (MSATs) and inferred lake surface temperatures (LSTs).

\begin{tabular}{|c|c|c|c|c|c|c|c|c|c|c|c|c|c|c|c|c|c|c|c|c|c|c|c|c|}
\hline \multirow[t]{2}{*}{ Basin $^{a}$} & \multirow[t]{2}{*}{$\begin{array}{l}\text { Depth } \\
\text { (m) }\end{array}$} & \multicolumn{2}{|c|}{$\begin{array}{c}\text { OS } \\
\text { coordinates }^{b}\end{array}$} & \multirow[t]{2}{*}{ Deployment } & \multirow[t]{2}{*}{ Collection } & \multicolumn{2}{|c|}{$\begin{array}{l}\text { [Crenarchaeol] } \\
\left(\mu \mathrm{g} \mathrm{m}^{-2} \mathrm{day}^{-1}\right)\end{array}$} & \multicolumn{2}{|c|}{$\begin{array}{c}\Sigma[\text { brGDGTs] } \\
\left(\mu \mathrm{g} \mathrm{m}^{-2} \text { day }^{-1}\right)\end{array}$} & \multirow[t]{2}{*}{$\begin{array}{l}\text { \%IPL } \\
\text { brGDGT }\end{array}$} & \multicolumn{2}{|c|}{ BIT } & \multicolumn{2}{|c|}{$\mathrm{MBT}^{\prime}$} & \multicolumn{2}{|c|}{ CBT } & \multicolumn{2}{|c|}{$\begin{array}{l}\text { MAAT - } \\
\text { soil }\left({ }^{\circ} \mathrm{C}\right)^{\mathrm{c}}\end{array}$} & \multicolumn{2}{|c|}{$\begin{array}{c}\text { MSAT - } \\
\text { lake }\left({ }^{\circ} \mathrm{C}\right)^{\mathrm{d}}\end{array}$} & \multicolumn{2}{|c|}{$\mathrm{TEX}_{86}$} & \multicolumn{2}{|c|}{$\operatorname{LST}\left({ }^{\circ} \mathrm{C}\right)^{\mathrm{e}}$} \\
\hline & & BNG & NS & & & IPL & $\mathrm{CL}$ & IPL & $\mathrm{CL}$ & & IPL & CL & IPL & CL & IPL & $\mathrm{CL}$ & IPL & $\mathrm{CL}$ & IPL & $\mathrm{CL}$ & IPL & $\mathrm{CL}$ & IPL & $\mathrm{CL}$ \\
\hline $\mathrm{S}$ & 7.5 & 38315 & 90165 & 13 May 2005 & 29 Jun 2005 & 0.1 & 0.3 & 0.6 & 2.8 & 17 & 0.88 & 0.90 & 0.39 & 0.45 & 1.10 & 1.16 & 6.7 & 8.1 & 16.1 & 16.7 & 0.51 & 0.52 & 14.3 & 14.9 \\
\hline $\mathrm{S}$ & 7.5 & 38315 & 90165 & 30 Jun 2005 & 4 Aug 2005 & 0.0 & 0.0 & 0.2 & 0.6 & 20 & 0.91 & 0.95 & 0.36 & 0.43 & 1.03 & 1.10 & 6.1 & 7.9 & 15.7 & 16.4 & 0.51 & 0.50 & 14.0 & 13.5 \\
\hline $\mathrm{S}$ & 7.5 & 38315 & 90165 & 4 Aug 2005 & 29 Aug 2005 & 0.0 & 0.0 & 0.2 & 0.8 & 21 & 0.88 & 0.95 & 0.32 & 0.38 & 0.92 & 0.99 & 5.6 & 6.9 & 15.3 & 16.3 & 0.51 & 0.44 & 14.4 & 10.6 \\
\hline S & 7.5 & 38315 & 90165 & 29 Sep 2005 & 29 Nov 2005 & 0.1 & 0.1 & 0.5 & 3.6 & 12 & 0.89 & 0.98 & 0.37 & 0.39 & 1.01 & 1.10 & 6.4 & 6.7 & 15.9 & 15.7 & 0.48 & 0.55 & 12.4 & 16.6 \\
\hline S & 7.5 & 38315 & 90165 & 30 Nov 2005 & 1 Feb 2006 & 0.1 & 0.4 & 0.6 & 3.5 & 14 & 0.79 & 0.88 & 0.37 & 0.38 & 0.98 & 1.06 & 6.6 & 6.6 & 16.4 & 15.8 & 0.45 & 0.46 & 10.8 & 11.3 \\
\hline$S$ & 7.5 & 38315 & 90165 & 31 Jan 2006 & 8 Mar 2006 & 0.3 & 0.7 & 1.4 & 4.1 & 26 & 0.83 & 0.84 & 0.43 & 0.38 & 1.00 & 1.08 & 8.4 & 6.5 & 16.9 & 15.6 & 0.51 & 0.45 & 14.0 & 11.0 \\
\hline $\mathrm{S}$ & 15 & 38315 & 90165 & 13 May 2005 & 29 Jun 2005 & 0.0 & 0.2 & 0.4 & 2.9 & 12 & 0.89 & 0.92 & 0.39 & 0.44 & 1.06 & 1.12 & 6.8 & 8.0 & 16.2 & 16.6 & 0.47 & 0.65 & 11.7 & 22.1 \\
\hline S & 15 & 38315 & 90165 & 30 Jun 2005 & 4 Aug 2005 & 0.1 & 0.3 & 0.6 & 4.4 & 12 & 0.89 & 0.94 & 0.37 & 0.41 & 1.02 & 1.11 & 6.3 & 7.1 & 15.9 & 15.8 & 0.47 & 0.52 & 11.7 & 14.7 \\
\hline S & 15 & 38315 & 90165 & 4 Aug 2005 & 29 Aug 2005 & 0.1 & 0.2 & 0.5 & 3.4 & 12 & 0.85 & 0.93 & 0.31 & 0.35 & 0.98 & 1.01 & 4.8 & 6.0 & 14.2 & 15.1 & 0.45 & 0.51 & 10.8 & 14.2 \\
\hline $\mathrm{S}$ & 15 & 38315 & 90165 & 29 Sep 2005 & 29 Nov 2005 & 0.0 & 0.2 & 0.4 & 4.2 & 8 & 0.90 & 0.95 & 0.35 & 0.37 & 1.01 & 1.06 & 6.0 & 6.4 & 15.6 & 15.5 & 0.46 & 0.53 & 11.3 & 15.3 \\
\hline $\mathrm{s}$ & 15 & 38315 & 90165 & 30 Nov 2005 & 1 Feb 2006 & 0.1 & 0.3 & 0.5 & 4.0 & 12 & 0.78 & 0.92 & 0.36 & 0.38 & 0.99 & 1.04 & 6.4 & 6.8 & 16.0 & 16.0 & 0.43 & 0.45 & 9.6 & 11.1 \\
\hline$S$ & 15 & 38315 & 90165 & 31 Jan 2006 & 8 Mar 2006 & 0.1 & 0.9 & 0.4 & 4.9 & 8 & 83 & 0.84 & 0.41 & 0.37 & 1.15 & 1.05 & 7.2 & 6.3 & 16.2 & 15.5 & 0.55 & 0.46 & 16.1 & 11.1 \\
\hline $\mathrm{LN}$ & 30 & 36538 & 94789 & 13 May 2005 & 29 Jun 2005 & 0.0 & 1.1 & 0.2 & 3.7 & 14 & 0.84 & 0.76 & 0.40 & 0.44 & 1.17 & 1.25 & 6.5 & 7.3 & 15.9 & 16.0 & 0.51 & 0.44 & 14.1 & 10.2 \\
\hline LN & 30 & 36538 & 94789 & 30 Jun 2005 & 4 Aug 2005 & 0.1 & 0.9 & 0.3 & 2.8 & 10 & 0.81 & 0.75 & 0.37 & 0.44 & 1.13 & 1.24 & 5.9 & 7.3 & 15.4 & 15.9 & 0.44 & 0.46 & 10.5 & 11.2 \\
\hline $\mathrm{LN}$ & 30 & 36538 & 94789 & 4 Aug 2005 & 29 Aug 2005 & 0.1 & 0.4 & 0.3 & 1.7 & 14 & 0.77 & 0.81 & 0.52 & 0.43 & 1.27 & 1.21 & 9.8 & 7.2 & 16.8 & 15.9 & 0.49 & 0.49 & 13.1 & 13.2 \\
\hline LN & 30 & 36538 & 94789 & 29 Sep 2005 & 29 Nov 2005 & 0.3 & 1.8 & 0.9 & 6.2 & 13 & 0.73 & 0.77 & 0.36 & 0.40 & 1.12 & 1.22 & 5.7 & 6.4 & 15.4 & 15.4 & 0.49 & 0.40 & 13.3 & 8.3 \\
\hline LN & 30 & 36538 & 94789 & 30 Nov 2005 & 1 Feb 2006 & 0.3 & 1.6 & 0.8 & 5.0 & 14 & 0.74 & 0.75 & 0.38 & 0.40 & 1.08 & 1.17 & 6.4 & 6.5 & 15.9 & 15.5 & 0.46 & 0.40 & 11.2 & 8.3 \\
\hline LN & 30 & 36538 & 94789 & 31 Jan 2006 & 8 Mar 2006 & 0.3 & 3.1 & 0.6 & 6.0 & 9 & 0.61 & 0.65 & 0.36 & 0.40 & 1.08 & 1.21 & 5.9 & 6.2 & 15.6 & 15.3 & 0.50 & 0.41 & 13.8 & 8.7 \\
\hline LN & 60 & 36538 & 94789 & 13 May 2005 & 29 Jun 2005 & 0.0 & 0.1 & 0.1 & 0.4 & 16 & 0.77 & 0.70 & 0.39 & 0.44 & 1.13 & 1.24 & 6.5 & 7.3 & 15.9 & 15.9 & 0.53 & 0.46 & 15.4 & 11.3 \\
\hline LN & 60 & 36538 & 94789 & 30 Jun 2005 & 4 Aug 2005 & 0.1 & 1.3 & 0.3 & 3.0 & 9 & 0.70 & 0.68 & 0.54 & 0.44 & 0.94 & 1.26 & 12.4 & 7.3 & 18.0 & 15.7 & 0.50 & 0.45 & 13.3 & 10.8 \\
\hline $\mathrm{LN}$ & 60 & 36538 & 94789 & 4 Aug 2005 & 29 Aug 2005 & 0.1 & 1.1 & 0.3 & 2.8 & 0 & 0.78 & 0.72 & 0.36 & 0.41 & 1.09 & 1.22 & 5.9 & 6.5 & 15.6 & 15.3 & 0.49 & 0.45 & 13.3 & 11.0 \\
\hline LN & 60 & 36538 & 94789 & 29 Sep 2005 & 29 Nov 2005 & 0.2 & 1.7 & 0.7 & 7.1 & 9 & 0.80 & 0.79 & 0.37 & 0.40 & 1.11 & 1.21 & 6.0 & 6.4 & 15.5 & 15.2 & 0.48 & 0.37 & 12.3 & 6.4 \\
\hline $\mathrm{LN}$ & 60 & 36538 & 94789 & 30 Nov 2005 & 1 Feb 2006 & 0.4 & 2.1 & 1.1 & 6.9 & 14 & 0.71 & 0.76 & 0.38 & 0.40 & 1.10 & 1.17 & 6.4 & 6.5 & 15.8 & 15.5 & 0.46 & 0.44 & 11.2 & 10.0 \\
\hline LN & 60 & 36538 & 94789 & 31 Jan 2006 & 8 Mar 2006 & 0.3 & 3.2 & 0.6 & 7.7 & 7 & 0.66 & 0.69 & 0.39 & 0.39 & 1.04 & 1.17 & 7.0 & 6.3 & 16.4 & 15.3 & 0.45 & 0.40 & 10.8 & 8.2 \\
\hline
\end{tabular}

${ }^{\mathrm{a}} \mathrm{S}$ - south, LN - lower north, UN - upper north, ${ }^{\mathrm{b}}$ Ordnance Survey coordinates, ${ }^{\mathrm{c}}$ Peterse12 calibration (Eq. 9), ${ }^{\mathrm{d}}$ Pearson11 calibration (Eq. 10), ${ }^{\mathrm{e}}$ Powers11 calibration (Eq. 11).

(IPL) and $6 \mathrm{ng} \mathrm{L}^{-1}$ (CL) near the bottom. IPL TEX 86 indices range from 0.54 to 0.58 in March but vary more widely in September, from 0.44 to 0.59 (Fig. 8). CL TEX 86 indices are generally lower (March: 0.43-0.47; September: 0.37-0.52). In September, both IPL and CL BIT indices decrease accordingly with depth. IPL BIT indices reach a minimum of 0.52 at $30 \mathrm{~m}$ depth, and CL BIT indices are at their lowest $(0.57)$ from 40 to $60 \mathrm{~m}$ depth. BrGDGT distributions do not vary widely with depth or season of sampling, so there is little scatter in MBT' and CBT/DC between March and September and between basins (Fig. 4a, b). IPL and CL brGDGT distributions are similar (Fig. 5g-k) and MBT' indices are comparatively constant throughout the profiles in both March and September, ranging between 0.35 and 0.39 in IPL brGDGTs and between 0.38 and 0.43 in CL brGDGTs. IPL and CL CBT indices are also relatively stable at ca. 1.1 (IPL) and 1.3 (CL).

In the upper north basin, SPM data are only available for September. BrGDGT concentrations show little variation with depth, at $1 \mathrm{ng} \mathrm{L}^{-1}$ (IPL) and ranging from 6 to $8 \mathrm{ng} \mathrm{L}^{-1}$ (CL; Table 2). The \%IPL of brGDGTs is also fairly constant, between 7 and $12 \%$. CL crenarchaeol concentrations increase with increasing depth, from less than $0.5 \mathrm{ng} \mathrm{L}^{-1}$ up to ca. $2 \mathrm{ng} \mathrm{L}^{-1}$ from 40 to $80 \mathrm{~m}$ depth, while IPL crenarchaeol rises slightly to just over $0 \mathrm{ng} \mathrm{L}^{-1}$ below $20 \mathrm{~m}$ depth. TEX $_{86}$ values range from 0.49 to 0.55 (IPL) and from 0.40 to 0.55 (CL). Both IPL and CL BIT indices decrease from ca. 0.95 in the top $20 \mathrm{~m}$ to 0.82 (IPL) and 0.77 (CL) at $40 \mathrm{~m}$ depth and remain low down to $80 \mathrm{~m}$ depth. BrGDGT distributions do not vary widely with season of sampling or basin (Fig. 5g-k); MBT' indices are constant in both IPL and CL
brGDGTs at around 0.39, although IPL and CL CBT ratios are notably higher in surface waters (IPL: 1.27; CL: 1.57) compared with $20 \mathrm{~m}$ depth and below (IPL: 1.15; CL: 1.31).

\subsubsection{Settling particles}

Fluxes of IPL brGDGTs contained in settling particles at $7.5 \mathrm{~m}$ depth in the south basin vary between 0.2 and $0.6 \mu \mathrm{g} \mathrm{m}^{-2} \mathrm{yr}^{-1}$ over most of the year and show a slightly higher value of $1.4 \mu \mathrm{g} \mathrm{m}^{-2} \mathrm{yr}^{-1}$ in late winter. At $15 \mathrm{~m}$ depth, just above the sediment, these fluxes are generally constant and range from 0.4 to $0.6 \mu \mathrm{g} \mathrm{m}^{-2} \mathrm{yr}^{-1}$ (Table 4). Fluxes of CL brGDGTs are higher than IPL brGDGTs, ranging from 0.6 to $4.1 \mu \mathrm{g} \mathrm{m}^{-2} \mathrm{yr}^{-1}$ at $7.5 \mathrm{~m}$ depth and reaching maximum values in late winter and minimum values in summer. At $15 \mathrm{~m}$ depth, fluxes range from 2.9 to $4.9 \mu \mathrm{g} \mathrm{m}^{-2} \mathrm{yr}^{-1}$ and show a dampened seasonal variation compared with those at $7.5 \mathrm{~m}$ depth. In the lower north basin, fluxes of IPL brGDGTs are between 0.2 and $0.9 \mu \mathrm{g} \mathrm{m}^{-2} \mathrm{yr}^{-1}$ at $30 \mathrm{~m}$ depth and between 0.1 and $1.1 \mu \mathrm{g} \mathrm{m}^{-2} \mathrm{yr}^{-1}$ at $60 \mathrm{~m}$ depth, just above the sediment. Fluxes of CL brGDGTs are between 1.7 and $6.2 \mu \mathrm{g} \mathrm{m}^{-2} \mathrm{yr}^{-1}$ at $30 \mathrm{~m}$ depth and between 0.4 and $7.7 \mu \mathrm{g} \mathrm{m}^{-2} \mathrm{yr}^{-1}$ at $60 \mathrm{~m}$ depth. Highest fluxes of IPL and CL brGDGTs occur over the period September-March. \%IPLs of brGDGTs range from 12 to $17 \%$ in settling particles from the south basin at $7.5 \mathrm{~m}$ depth and from 8 to $12 \%$ at $15 \mathrm{~m}$ depth. In the lower north basin, \%IPL proportions are between 9 and $14 \%$ at $30 \mathrm{~m}$ depth and between 7 and $16 \%$ at $60 \mathrm{~m}$ depth. \%IPLs are generally higher in the settling particles collected in sediment traps situated mid-water column, rather than those just above the sediment. 
Table 5. Surface sediment data: crenarchaeol and summed brGDGT concentrations, BIT indices, MBT $^{\prime}$ indices, CBT ratios, TEX $_{86}$ indices, inferred mean annual air temperatures (MAATs), inferred mean summer air temperatures (MSATs) and inferred lake surface temperatures (LSTs).

\begin{tabular}{|c|c|c|c|c|c|c|c|c|c|c|c|c|c|c|c|c|c|c|c|c|c|c|c|c|c|}
\hline \multirow[t]{2}{*}{$\begin{array}{l}\text { Sample } \\
\text { name }\end{array}$} & \multirow[t]{2}{*}{ Basin $^{\mathrm{a}}$} & \multirow{2}{*}{\multicolumn{2}{|c|}{$\begin{array}{l}\text { Water } \\
\text { depth } \\
\text { (m) }\end{array}$}} & \multirow{2}{*}{\multicolumn{3}{|c|}{ OS coordinates ${ }^{b}$}} & \multicolumn{2}{|c|}{$\begin{array}{l}\text { [Crenarchaeol] } \\
\text { (ng g }{ }^{-1} \text { dry wt.) }\end{array}$} & \multicolumn{2}{|c|}{$\begin{array}{c}\Sigma[\text { brGDGTs] } \\
\text { (ng g }{ }^{-1} \text { dry wt.) }\end{array}$} & \multirow[t]{2}{*}{$\begin{array}{l}\% \text { IPL } \\
\text { brGDGT }\end{array}$} & \multicolumn{2}{|c|}{ BIT } & \multicolumn{2}{|c|}{$\mathrm{MBT}^{\prime}$} & \multicolumn{2}{|c|}{ CBT } & \multicolumn{2}{|c|}{$\begin{array}{l}\text { MAAT - } \\
\text { soil }\left({ }^{\circ} \mathrm{C}\right)^{\mathrm{c}}\end{array}$} & \multicolumn{2}{|c|}{$\begin{array}{l}\text { MSAT - } \\
\text { lake }\left({ }^{\circ} \mathrm{C}\right)^{\mathrm{d}}\end{array}$} & \multicolumn{2}{|c|}{$\mathrm{TEX}_{86}$} & \multicolumn{2}{|c|}{$\operatorname{LST}\left({ }^{\circ} \mathrm{C}\right)^{\mathrm{e}}$} \\
\hline & & & & & & & IPL & $\mathrm{CL}$ & IPL & $\mathrm{CL}$ & & IPL & $\mathrm{CL}$ & IPL & $\mathrm{CL}$ & IPL & CL & IPL & CL & IPL & CL & IPL & CL & IPL & $\mathrm{CL}$ \\
\hline P1 & $\mathrm{S}$ & 15.4 & BNG & 38315 & NS & 90165 & 35 & 11 & 23 & 220 & 9 & 0.33 & 0.94 & 0.39 & 0.41 & 0.61 & 0.77 & 9.4 & 9.3 & 19.3 & 17.5 & 0.66 & 0.50 & 22.2 & 13.6 \\
\hline $\mathrm{P} 2$ & $\mathrm{~S}$ & 3.3 & BNG & 1851 & NS & 90279 & 7.0 & 20 & 10 & 1900 & 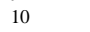 & 0.96 & 0.99 & 0.29 & 0.31 & 0.83 & 0.90 & 5.1 & 5.4 & 15.8 & 15.7 & 0.45 & 0.60 & 10.7 & 19.1 \\
\hline P3 & $\mathrm{S}$ & 7.3 & BNG & 41193 & NS & 90054 & 41 & 54 & 220 & 1400 & & 0.82 & 0.96 & 0.28 & 0.35 & 0.79 & 0.87 & 5.1 & 6.6 & 15.2 & 16.1 & 0.47 & 0.45 & 12.2 & 10.7 \\
\hline $\mathrm{P} 4$ & $\mathrm{~S}$ & 12 & BNG & 40922 & NS & 90867 & 5.1 & 87 & 230 & 4200 & 5 & 0.98 & 0.98 & 0.26 & 0.29 & 0.74 & 0.81 & 4.6 & 5.3 & 14.3 & 15.0 & 0.49 & 0.56 & 13.1 & 17.1 \\
\hline P5 & LN & 67.5 & BNG & 5 & NS & 94789 & 24 & 290 & 270 & 42 & 0 & 0.91 & 0.93 & 0.22 & 0.26 & 0.94 & 1.01 & 2.2 & 3.1 & 10.4 & 11.4 & 0.44 & 0.46 & 10.0 & 11.2 \\
\hline P6 & $\mathrm{LN}$ & 56.3 & BNG & 35510 & NS & 95222 & 100 & 280 & 480 & 3300 & 13 & 0.81 & 0.92 & 0.28 & 0.32 & 0.92 & 1.01 & 4.2 & 4.9 & 13.0 & 13.3 & 0.47 & 0.49 & 12.1 & 12.9 \\
\hline P7 & UN & 70.2 & BNG & 33562 & NN & 0373 & 47 & 530 & 660 & 7300 & 8 & 0.93 & 0.93 & 0.27 & 0.28 & 0.91 & 1.07 & 3.9 & 3.5 & 12.0 & 11.7 & 0.58 & 0.46 & 17.8 & 11.4 \\
\hline P8 & UN & 64 & BNG & 33215 & NN & 09853 & 1.8 & 130 & 60 & 2900 & 2 & 0.97 & 0.96 & 0.36 & 0.35 & 1.15 & 1.20 & 5.3 & 4.9 & 14.1 & 13.6 & 0.60 & 0.54 & 19.0 & 15.7 \\
\hline
\end{tabular}

${ }^{a} \mathrm{~S}$ - south, LN - lower north, UN - upper north, ${ }^{\mathrm{b}}$ Ordnance Survey coordinates, ${ }^{\mathrm{c}}$ Peterse12 calibration (Eq. 9), ${ }^{\mathrm{d}}$ Pearson11 calibration (Eq. 10), ${ }^{\mathrm{e}}$ Powers11 calibration (Eq. 11).

CL crenarchaeol fluxes are generally low throughout the year (Table 4), with maxima in the final period of sampling, which falls almost entirely within the month of February, and minima during the summer months. In the south basin, CL fluxes range from 0.0 to $0.7 \mu \mathrm{g} \mathrm{m}^{-2} \mathrm{yr}^{-1}$ at $7.5 \mathrm{~m}$ depth and between 0.2 and $0.9 \mu \mathrm{g} \mathrm{m}^{-2} \mathrm{yr}^{-1}$ at $15 \mathrm{~m}$ depth. CL fluxes are higher in the lower north basin and range from 0.4 to $3.1 \mu \mathrm{g} \mathrm{m}^{-2} \mathrm{yr}^{-1}$ at $30 \mathrm{~m}$ depth; at $60 \mathrm{~m}$ depth, fluxes range from 0.1 to $3.1 \mu \mathrm{g} \mathrm{m}^{-2} \mathrm{yr}^{-1}$. IPL crenarchaeol fluxes are an order of magnitude lower, ranging from 0.0 to $0.4 \mu \mathrm{g} \mathrm{m}^{-2} \mathrm{yr}^{-1}$. Flux-weighted average \%IPL crenarchaeol is 10 and $11 \%$ in the lower north basin (upper and lower water column, respectively), while in the south basin this is 28 and $20 \%$ in the upper and lower water column, respectively. In the south basin, flux-weighted average IPL TEX 86 indices are 0.48 and 0.47 (7.5 and $15 \mathrm{~m}$ depth, respectively), and CL TEX 86 indices yield flux-weighted averages of 0.42 at both depths. In the lower north basin, flux-weighted average IPL TEX $\mathrm{T}_{86}$ indices are 0.48 and 0.46 (30 and $60 \mathrm{~m}$ depth, respectively); flux-weighted average $\mathrm{CL} \mathrm{TEX}_{86}$ indices are 0.49 and 0.51 ( 30 and $60 \mathrm{~m}$ depth, respectively).

IPL and CL BIT indices in the south basin are high, ranging from 0.84 to 0.98 (CL) and from 0.79 to 0.91 (IPL) over the time series at $7.5 \mathrm{~m}$ depth (Table 4). At $15 \mathrm{~m}$ depth, BIT indices are similarly high and range from 0.84 to 0.95 (CL) and from 0.78 to 0.90 (IPL). Lower BIT indices ( $<0.85$ for IPL and $<0.90$ for CL GDGTs) generally occur in the south basin towards the end of the time series, encompassing December to February, indicating that crenarchaeol fluxes at these times are higher relative to brGDGT fluxes. In the lower north basin BIT indices are lower, with values between 0.65 and $0.81(\mathrm{CL})$ and between 0.61 and 0.84 (IPL) at $30 \mathrm{~m}$. At $60 \mathrm{~m}$ depth, BIT indices range from 0.68 to 0.79 (CL) and from 0.66 to 0.80 (IPL). In February, towards the end of the time series, BIT indices are generally low. Although brGDGT distributions do not vary widely, they do show a shift by basin, with a lower proportion of cyclised brGDGTs found in the lower north basin in comparison to the south basin (Table 2). CL MBT' values are relatively constant at ca. 0.40 throughout the time series in both basins; MBT' values in IPLs are generally similar to those in CLs. CL CBT values range from 0.99 to 1.16 (IPL: 0.92-1.15) in the south basin, while in the lower north basin CL CBT values are higher, ranging from 1.17 to 1.26 (IPL: $0.94-1.27$ ).

\subsubsection{Sediments}

Concentrations of IPL brGDGTs in lake sediments range between $0.02 \mu \mathrm{g} \mathrm{g}^{-1}$, from the south basin at $15.4 \mathrm{~m}$ depth, to $0.66 \mu \mathrm{g} \mathrm{g}^{-1}$ dry weight sediment, from the upper north basin at $70.2 \mathrm{~m}$ depth. CL brGDGT concentrations are higher, ranging from $0.22 \mu \mathrm{g} \mathrm{g}^{-1}$ (S basin) to $7.30 \mu \mathrm{g} \mathrm{g}^{-1}$ dry weight sediment (upper north basin; Table 5). There are no clear trends in concentration with depth or between north and south along the eutrophic gradient. The \%IPL of brGDGTs ranges from 5 to $14 \%$. IPL and CL crenarchaeol concentrations are generally low in the south basin, ranging from 0.01 to $0.04 \mu \mathrm{g} \mathrm{g}^{-1}$ (IPL) and from 0.01 to $0.09 \mu \mathrm{g} \mathrm{g}^{-1}$ (CL). IPL crenarchaeol concentrations are similar in the north basin; however, CL crenarchaeol concentrations are an order of magnitude higher in the lower north (ca. $0.3 \mu \mathrm{g} \mathrm{g}^{-1}$ ) and upper north $\left(0.13-0.53 \mu \mathrm{g} \mathrm{g}^{-1}\right)$ basins than in the south basin. IPL $\mathrm{TEX}_{86}$ indices range from 0.44 to 0.66 ; $\mathrm{CL} \mathrm{TEX}_{86}$ indices are similar, ranging from 0.45 to 0.60 .

IPL BIT indices do not demonstrate any notable trends (Table 5), varying between 0.81 and 0.98 . This excludes a single value of 0.33 in the south basin at $15.4 \mathrm{~m}$ depth, which may be dismissed since this BIT index has been calculated using low concentrations of both crenarchaeol and brGDGTs; indeed, the CL BIT index for this sample is high (0.94) and in line with the other samples. CL BIT indices are generally slightly higher in the south basin (0.94-0.99) than in the upper and lower north basin (0.93-0.96). BrGDGT distributions vary with depth (Fig. 5p, q); MBT' indices vary from 0.22 to 0.39 (IPL) and from 0.26 to 0.41 (CL). CBT ratios are lower, on average, in IPL compared with CL brGDGTs ( 0.86 vs. 0.96 ). IPL CBT ratios range from 0.61 to 1.15 and CL CBT ratios from 0.77 to 1.20 . In this case, there is a general increase in IPL and CL CBT the further north the samples originate from. 


\section{Discussion}

\subsection{BrGDGTs from source to sink}

The relatively large catchment area of Loch Lomond (catchment to surface area ratio of ca. 11) is almost entirely soil covered, of which a large portion is peaty soils. This means that soil-derived brGDGT influxes would be expected to contribute considerably to GDGTs found in lake sediments, so 13 soils were sampled around the lake and its catchment area (Fig. 1) to characterise the distributions of soil-derived brGDGTs. Although the results show a substantial variability in brGDGT composition between individual soils, overall they are characterised by higher IPL and CL MBT' and higher (although variable) DC values in comparison with other sample groups (Fig. 4). Generally lower CL DC, and thus higher CBT ratios, are found in soils from the northern catchment area of the lake, which lead to slightly lower reconstructed $\mathrm{pH}$ values (means of 5.3 compared with 5.8 in the south; Table 1). This fits with the bisection of Loch Lomond by the Highland Boundary Fault (e.g. Pierce, 1999), which results in the domination of the northern catchment by base-poor soils and the south by base-rich soils. MBT' does not reflect this spatial difference between north and south, in line with its stronger documented relationship to temperature rather than $\mathrm{pH}$ (e.g. Weijers et al., 2007a; Peterse et al., 2012). Areas of different land use and vegetation cover do not appear to affect brGDGT distributions in a characteristic manner, with the exception of peaty soils due to their increased acidity.

As streams and rivers transport eroded soil material to the lake, river sediments are expected to provide a more integrated soil-derived brGDGT signal in comparison to the relatively heterogeneous soils. Contrary to this expectation, however, river sediments and SPM show somewhat lower CL and IPL MBT' indices than soils (Fig. 4a, b). This small change in distribution might point to some brGDGT production within the river water or in the river sediments themselves. The \%IPL of brGDGTs in river sediments, an indicator of the proportion of living brGDGT-producing bacteria to the older CL brGDGTs, is somewhat higher than the \%IPL found within soils (15 vs. $11 \%$, respectively). Although this difference is not statistically significant, (Student's $t$ test: $p=0.22$ ), it is unlikely that all of the soilderived brGDGT-producing bacteria or their IPL brGDGTs are preserved when eroded from soils into the streams and rivers. For example, some of the more labile IPL GDGTs, such as the phosphoglycolipids that correlate well with living biomass (e.g. Pitcher et al., 2009b; Schubotz et al., 2009; Lengger et al., 2012; Buckles et al., 2013), would likely be degraded during transport, resulting in lower instead of higher \%IPL values. The turnover time for attached and free-living bacteria in rivers has been previously reported at around two weeks (Edwards and Meyer, 1986), supporting the assumption that IPL brGDGTs in rivers represent the living brGDGT-producing community. Previous studies of brGDGTs in rivers also rely on this assumption (e.g. Kim et al., 2012; Zell et al., 2013a, b). There is no statistically significant difference in CL brGDGT distributions between river water SPM and river surface sediments (Appendix 2), suggesting they share a similar source of brGDGTs. The difference between IPL and CL CBT values in riverine samples is statistically significant (95\% confidence interval; paired $t$ test, $p<0.01)$. As IPL brGDGTs are suggested to largely represent those produced in situ and CL brGDGTs will most likely also represent those GDGTs washed in from soils, this offset in CBT ratios between the two supports the idea that brGDGTs may be produced even within the small rivers and streams sampled in this study, in different distributions to those found in soils. Differences in brGDGT distributions between river SPM and soils are slightly smaller than between river sediments and soils, notably demonstrated by the similar soil and river SPM CL CBT and DC ratios. This suggests that river SPM may contain a larger proportion of soil brGDGTs associated with soil-derived clay particles.

In situ riverine production has been observed previously in large rivers. For example, Kim et al. (2012) and Zell et al. (2013a, b) analysed SPM from the Amazon River and its Tapajós River and Negro River tributaries, finding differences in brGDGT distributions between soil and river SPM. This was considered to indicate in situ riverine brGDGT production in the Amazon River and its Tapajós River tributary, although brGDGT distributions in the Negro River were still rather similar to those in surrounding soil. In situ production of brGDGTs in rivers is, therefore, not unique to Loch Lomond; however, the results presented in this study now suggest that in situ production occurs here and is noticeable even in small streams. Obviously this implies that, in addition to soil-derived brGDGTs, riverine-derived brGDGTs may also end up in the lake sedimentary archive. Nonetheless, this data set is rather small and more research is needed, including specifically looking at differences in preservation potential between the different sources.

Notably, a waterlogged soil originating from a marshy area along the bank of Falloch Water shows a distinctive brGDGT distribution (S10, Table 1), not seen in another waterlogged soil from a grassy field (S1). Although here we observe an "aquatic" bias solely in the river-adjacent waterlogged soil, in a study of western Ugandan lakes and soils, Loomis et al. (2011) proposed that water saturation might play a role in this shift in brGDGT distributions. It is possible that differences in distribution between waterlogged samples here may be related to the (unknown) duration of water saturation rather than the proximity of river water, since similar shifts in brGDGT distributions noted by Loomis et al. (2011) were only observable in perennially saturated Rwenzori soils. However, any effect of differences in vegetation cannot yet be excluded.

In the sediments of Loch Lomond, $8 \%$ of the total brGDGTs are (on average) present as IPLs (Table 5). The 

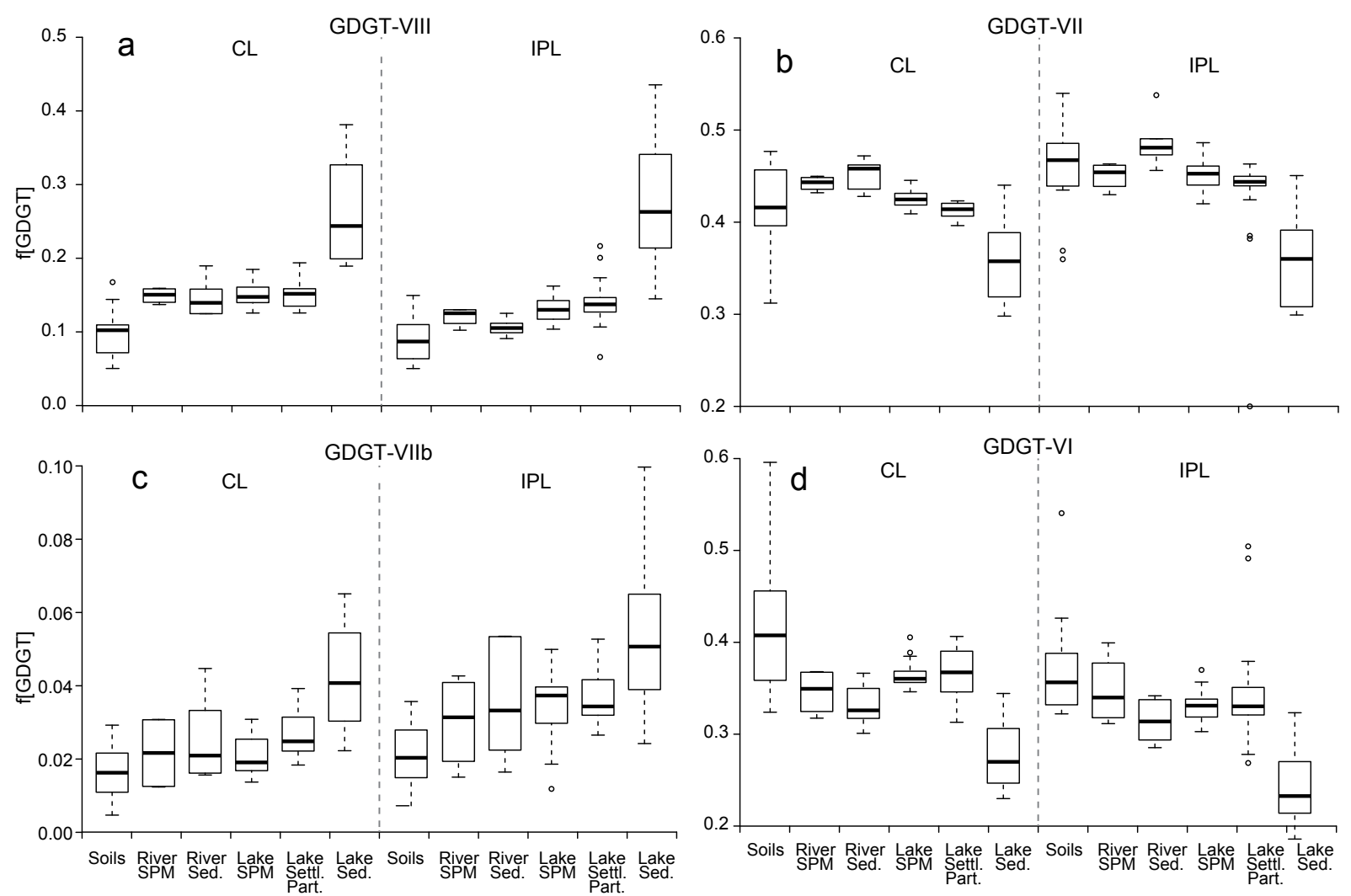

Figure 6. Boxplots of fractional abundances of (a) GDGT-VIII, (b) GDGT-VII, (c) GDGT-VIIb and (d) GDGT-VI in different sample groups for both IPLs and CLs; Note the differences of scale on the $y$ axes. The box corresponds to the interquartile range (25-75\%), and the whiskers extend to 1.5 times the interquartile range (unless the full range of data is smaller than this); outliers are defined here as being outside the maximum extent of the whiskers. The black horizontal line inside the box represents the median.

mere presence of these IPL brGDGTs in Loch Lomond sediments, in similar proportions relative to those seen in soils, is suggestive of their in situ production within the lake itself. BrGDGT distributions in lake sediments are notably different when compared to soils (Fig. 5a, b, p, q). All major GDGTs differ significantly in their mean fractional abundances between soils and lake sediments (Fig. 6a-d). Most notable is that lake sediments contain significantly higher proportions of IPL and CL GDGT VIII than soils (Figs. 5a, b, p, q, 6a), as reflected in generally lower mean IPL and CL MBT' indices (Fig. 4). Mean IPL and CL DC ratios are generally higher in lake sediments compared with soils (Fig. 4), due to significantly higher proportions of GDGT VIIb in lake sediments (Fig. 6c; MANOVA analysis, Appendix 2). In fact, lake sediment brGDGT distributions have generally lower MBT' and higher DC values than any other sample group (Fig. 4; MANOVA analysis, Appendix 2). There is also a clear difference between CL and IPL CBT and DC values in lake sediments, with south basin sediments yielding the lowest CBT values (Table 5).

Having examined the differences in distribution between sample groups closely (Fig. 5a-q; MANOVA analysis), it is clear that soils, river sediments and lake sediments emerge as discrete groups with statistically different mean GDGT distributions (Appendix 2). This is consistent with observations made of soil and lake sediment brGDGT distributions by Tierney and Russell (2009) in the tropical Lake Towuti (Indonesia) and by Loomis et al. (2011) in lower elevation lakes (below $1500 \mathrm{~m}$ a.s.1.) in Uganda, where CL MBT and CBT values were found to be higher in the surrounding soils than in lake sediments. This trend was also observed in a kettle pond (Sand Pond, US) (Tierney et al., 2012) and in a hyper-eutrophic, polluted South African lake (Das et al., 2012) based on differences in brGDGT distributions between soils and lake sediments. In these lakes it was similarly suggested that brGDGTs are produced in situ in the lake system. In equatorial Lake Challa (East Africa), brGDGTs in lake sediments were found to originate mainly from the suboxic zone of the water column rather than from soil influxes to the lake, based on differences in brGDGT distributions, \%IPLs and BIT indices in multiple sample sets (Buckles et al., 2014). Where most other lakes studied were tropical and/or generally characterised by relatively small catchment areas (Tierney and Russell, 2009; Loomis et al., 2011; Das et al., 2012; Tierney et al., 2012; Buckles et al., 2014), in Loch Lomond these differences are more remarkable because the 


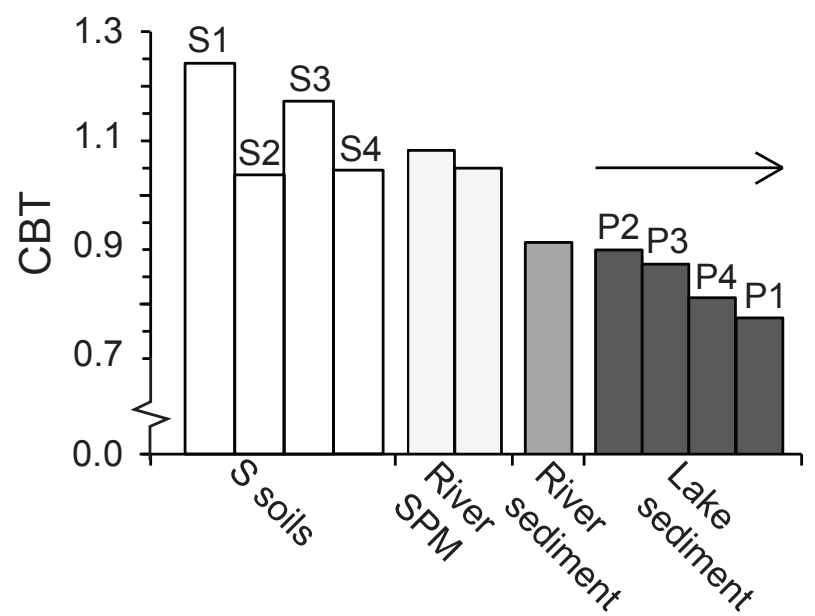

Figure 7. CL CBT ratios of soils from the south catchment area; river SPM and river sediment from Endrick Water (south basin); and lake sediments from the south basin (labelled). The arrow indicates the increasing distance from the mouth of Endrick Water and increasing water depth of the lake sediments.

lake has a large catchment area and receives high influxes of soil- and peat-derived organic matter (Bayfield and Conroy, 1995; after Soil Survey of Scotland, 1982) presumably containing substantial amounts of predominantly CL brGDGTs (e.g. Weijers et al., 2006a, b). The fact that clear differences between soil and lacustrine brGDGT distributions are present indicates not only that in situ production also occurs within temperate lakes but also that this production significantly alters the CL brGDGT signature derived from a large, peat-rich catchment area.

\subsection{Lacustrine production}

Based on the significantly different brGDGT distribution in Loch Lomond sediments, it is clear that the in situ production of brGDGTs must occur within the lake. However, where exactly in the lake system this production occurs, i.e. in the upper or lower water column or in sediments, is still unclear. In order to further constrain the location(s) of in situ brGDGT production, SPM depth profiles and settling particles (representing nearly a year of export from the water column) at several locations in Loch Lomond were analysed for brGDGTs.

BrGDGT distributions in lake SPM and settling particles are significantly different to those found in lake sediments (Fig. 6). Flux-weighted mean MBT' values of 0.40 (CL) and 0.38 (IPL) and mean CBT values of 1.13 (CL) and 1.05 (IPL) in settling particles are both high compared with mean lake sediment values (MBT' CL: 0.32; IPL: 0.29; CBT CL: 0.96; IPL: 0.86). Since CBT ratios of IPL brGDGTs, considered to be representative of the living community, are significantly lower than those of CL brGDGTs ratios in lake sediments (Student's paired $t$ test, $p<0.001$ ), this suggests that brGDGTs are produced within sediments with lower
CBT ratios than seen in other sample groups (lower DC ratios; Fig. 4). BrGDGTs must, therefore, also be produced within lake sediments, most likely by different bacterial communities that produce brGDGTs with different degrees of methylation and cyclisation. In turn, these in situ produced IPL brGDGTs degrade to CL brGDGTs, meaning that CL brGDGTs in sediments are likely a mixture of sedimentary, soil and potentially water-column-derived brGDGTs.

Tracing the brGDGT signal observed in SPM and sediment from Endrick Water across the south basin, its influence on lake sediments appears to stretch across the basin; along a transect of increasing depth away from Endrick Water, lake sediments yield CL CBT values that decrease from 0.90 to 0.77 (3 to $15 \mathrm{~m}$ depth; Fig. 7; Table 5). In comparison, a sediment from Endrick Water yields a CL CBT of 0.91, Endrick Water SPM yields a CL CBT of ca. 1.05 and soils from the south catchment show an even higher average value of 1.12 $( \pm 0.10)$. The fact that the CL CBT value decreases, rather than increases, in a transect away from the river inflow indicates that it is not a recalcitrant soil signal that emerges due to remineralisation of riverine produced brGDGTs. Instead this points again to the influence of in situ production of brGDGTs in lake sediments. This transect away from Endrick Water also corresponds with increasing depth, but conditions in the water column of the south basin were found to be relatively homogeneous with depth in March and September (Fig. 3), so brGDGTs are likely not responding to a gradation of ambient environmental change with depth.

Tierney et al. (2012) previously concluded that increased proportions of more highly methylated brGDGTs with depth in a sediment core from a small $\left(0.05 \mathrm{~km}^{2}\right)$ kettle pond (Sand Pond, RI, USA) potentially indicated sedimentary production. The study of Lake Challa also suggested but could not confirm production of brGDGTs in lake sediments (Buckles et al., 2014) because of the similarities between the brGDGT distributions of potentially sedimentary brGDGTs and those from other sources. In Loch Lomond it is clear from differences in MBT' and CBT ratios that a noticeable proportion of brGDGTs are produced in situ in lake sediments. Although low concentrations of potentially in situ produced brGDGTs were found in the oxic water column of Lake Challa, the vast majority of brGDGT production there was found within the suboxic/anoxic water column and potentially also in anoxic sediments (Buckles et al., 2014). Likewise, Sand Pond sediments are anoxic (Tierney et al., 2012). Loch Lomond and its surface sediments, however, are well oxygenated, except perhaps for the deepest sediments in the north basin (Figs. 1 and 3 ), but these could not be obtained for this study. Again, unlike Lake Challa and Sand Pond, the catchment area of Loch Lomond is large and peat-rich and so is expected to provide higher proportions of allochthonous brGDGTs to lake sediments. The fact that in situ sedimentary production in this lake system can measurably shift brGDGT distributions away from those of allochthonous brGDGTs means that it constitutes a considerable level of production. 
In comparison with the other sample groups, lacustrine SPM brGDGT distributions (both CL and IPL) are closest to those from lacustrine settling particles, riverine SPM and river sediments (Fig. 4a, b); there is no significant difference between river SPM and lake SPM, or between lake SPM and settling particles (MANOVA analysis; Appendix 2). However, the close correspondence in brGDGT distributions of lake water SPM and river SPM or river sediment (Fig. 4a, b) suggests either that brGDGTs in the lake are solely accounted for by riverine production or that brGDGTs are also produced within the lake's water column with similar distributions to those seen in the rivers. At first sight, the MBT' indices of both the IPL and CL fractions appear to be similar throughout the SPM depth profiles; however, there is no correlation between the two fractions in individual samples $\left(r^{2}=0.00\right)$, and a paired Student's $t$ test reveals that IPL vs. CL MBT' indices in lake SPM are statistically significantly different (95\% confidence interval; paired $t$ test, $p<0.01$ ). The difference between CLs and IPLs is clearer in the CBT ratios: CL CBT values in lake water SPM approach values seen in soils (Table 2) and so are higher than IPL CBT values (mean difference of 0.18 ) regardless of water depth, basin and sampling month. Thus, the IPL brGDGTs found in lake SPM likely comprise a considerable fraction produced in situ rather than transported from an external source, while CL brGDGTs may have a primarily allochthonous source. Notably, and in contrast to IPL CBT values, CL CBT values in SPM and settling particles are higher in the lower and upper north basin than in the south basin (Tables 3 and 4). Similar trends from the south to north basins were observed in soil brGDGT distributions, related mainly to differences in catchment soil pH (Sect. 4.1). This confirms that in contrast to a previous study of Lake Challa, which found that in situ production in the water column overwhelmed soil-derived brGDGTs (Buckles et al., 2014), CL brGDGT soil input is still readily traceable in the water column of Loch Lomond.

In situ production of brGDGTs in the lake's water column occurs at all depths, as evidenced by the relatively constant concentrations and distributions of IPL brGDGTs in SPM with depth. Although the bacteria that produce brGDGTs in soils were postulated to be anaerobes or facultative aerobes (Weijers et al. 2006a, b), IPL brGDGT concentrations in SPM are approximately similar with depth and with season and in some cases even higher in March (fully mixed) compared with September (thermally stratified) (Table 2). Thus, they do not seem to be restricted to a time or location of enhanced oxygen depletion. Zell et al. (2013a) also concluded that brGDGTs were derived from in situ production in the water columns of oxygenated floodplain lakes along the Amazon River and its tributaries, albeit with a substantial allochthonous component. These reports of ostensible brGDGT production in aerobic environments are supported by aerobic Acidobacterium strains that were found to produce brGDGTs, albeit only one type (i.e. GDGT-VI: Sinninghe Damsté et al., 2011).
In summary, brGDGTs appear to be produced in a variety of settings within Loch Lomond. Earlier studies, based mainly on comparison of soils with lake sediments, suggested an additional brGDGT source within the lake system. At Loch Lomond, lake SPM and settling particles contain different brGDGT distributions than soils. IPL brGDGT distributions appear to relate more directly to in situ production within the lake water column, while CL brGDGT distributions in the lake water column show a considerable allochthonous signal. BrGDGT distributions in lake sediments, with lower MBT' and CBT values than were found in any of the other sample groups, are strongly indicative of aquatic brGDGT production that significantly shifts CL brGDGT distributions in sediments.

\subsection{Implications for palaeothermometry: MBT-CBT}

Inevitably, since each individual lake is different in its chemistry and catchment and thus in the ratio of allochthonous to autochthonous brGDGTs, the accuracy of brGDGTinferred temperature estimates based on lake-sedimentderived brGDGT distributions will depend on the selection of lakes included in the calibration data set. Regional lake calibrations cover New Zealand (Zink et al., 2010), parts of China and Nepal (Sun et al., 2011; Sun11), saline lakes on the Tibetan Plateau (Günther et al., 2013) and equatorial Africa (Tierney et al., 2010; Loomis et al., 2012) (Table 6). The Pearson11 calibration ranges from the Scandinavian Arctic to the Antarctic, constituting a wide variety of sites, including those within the Arctic Circle (Finland, Sweden and Siberia), the UK, Austria, Turkey, Ethiopia, Uganda, Chile, South Georgia and the Antarctic Peninsula and yet demonstrating good correlation statistics $\left(r^{2}=0.88\right.$; RMSE $\left.=2.0^{\circ} \mathrm{C}\right)$. In contrast to all other calibrations, brGDGT distributions from lake sediments in the Pearson et al. (2011) study were calibrated to annual MSAT rather than annual mean air temperature. This is due to the inclusion of Arctic lakes in the calibration, where brGDGT-inferred temperatures have subsequently shown bias towards summer air temperatures (Shanahan et al., 2013). However, of the different regional calibration sets, the Pearson11 lake calibration is the only one that covers temperate lakes in the Northern Hemisphere, including sites within the UK. Consequently, this seems to be the most appropriate calibration for application to Loch Lomond in order to assess the effects of the multiple sources of brGDGTs, identified here, on temperature estimates from sediments.

In Loch Lomond, MAAT/MSAT estimates from soils, river sediments and lake sediments vary considerably, as expected from their different brGDGT distributions (see Sect. 4.1). Applying the Peterse12 global soil calibration to CL brGDGTs in Loch Lomond sediments yields generally low MAAT estimates (i.e. ca. $4{ }^{\circ} \mathrm{C}$ lower than measured annual MAAT of $9.5^{\circ} \mathrm{C} ; 1980-2010$, Table 5). This has been reported previously in other lakes as the general rule rather 
Table 6. Details of MBT-CBT calibrations and inferred MAATs from Loch Lomond sediments.

\begin{tabular}{|c|c|c|c|c|c|c|c|c|}
\hline $\begin{array}{l}\text { MBT-CBT } \\
\text { calibrations }\end{array}$ & Lakes & Sediments & $\begin{array}{l}\text { MAAT calibration } \\
\text { range }\left({ }^{\circ} \mathrm{C}\right)\end{array}$ & $\begin{array}{l}\text { Elevation calibration } \\
\text { range (m a.s.1.) }\end{array}$ & $\begin{array}{l}\text { Lake depth } \\
\text { calibration } \\
\text { range }(\mathrm{m})\end{array}$ & Region & $\begin{array}{l}\text { Calibration } \\
\text { error }\left({ }^{\circ} \mathrm{C}\right)\end{array}$ & $\begin{array}{l}\text { Loch Lomond } \\
\text { inferred MAAT } \\
\left({ }^{\circ} \mathrm{C}\right)\end{array}$ \\
\hline Tierney $10^{\mathrm{a}}$ & 41 & 41 & 1.5 to 9.9 & 770 to 4500 & $<1$ to 110 & East Africa & \pm 2.2 & $9.9( \pm 3.9)$ \\
\hline Zink $10^{\mathrm{b}}$ & 11 & 14 & 1.5 to 9.9 & 101 to 2000 & 3.8 to 28.7 & New Zealand & n.a. & $11.5( \pm 2.6)$ \\
\hline Pearson $11^{\mathrm{c}}$ & 90 & 90 & 1.6 to $31.2^{\mathrm{a}}$ & 2.5 to 2260 & $<1$ to 141.0 & Global; mainly European & \pm 2.0 & $14.3( \pm 2.1)$ \\
\hline Sun $11^{\mathrm{d}}$ & 24 & 36 & -2.8 to 23.3 & n.a. ${ }^{\mathrm{f}}$ & $<1$ to 127.0 & China and Nepal & \pm 5.2 & $10.8( \pm 2.2)$ \\
\hline Loomis $12^{\mathrm{e}}$ & 111 & 111 & 1.6 to 26.8 & 615 to 4752 & $<1$ to 180.0 & East Africa & \pm 2.0 & $8.7( \pm 2.4)$ \\
\hline
\end{tabular}

a Tierney et al. (2010); ${ }^{b}$ Zink et al. (2010); ${ }^{\mathrm{c}}$ Pearson et al. (2011), yields mean summer air temperatures (MSATs); ${ }^{\mathrm{d}}$ Sun et al. (2011); ${ }^{\mathrm{e}}$ Loomis et al. (2012); ${ }^{\mathrm{f}}$ data not available; ${ }^{\mathrm{g}}$ based on sediment brGDGT distributions.

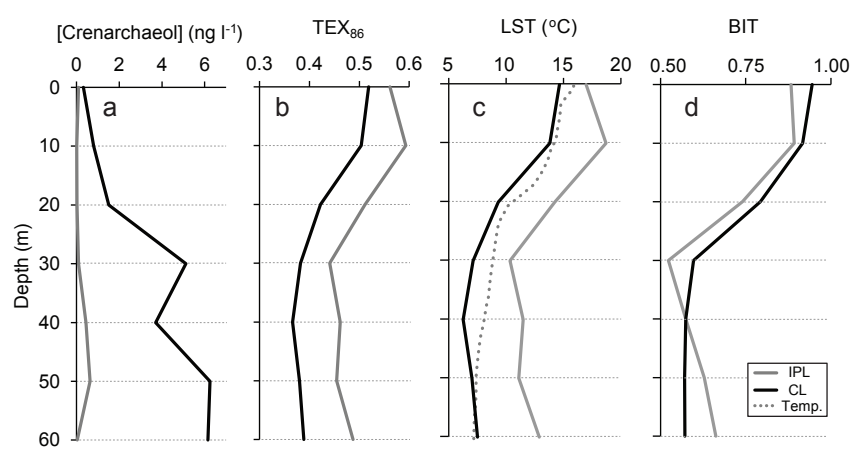

Figure 8. September SPM profiles in the lower north basin of (a) crenarchaeol concentrations, (b) TEX $_{86}$ values, (c) TEX $_{86}$-inferred temperatures using the Powers et al. (2010) calibration and measured in situ temperatures and (d) BIT indices.

than as an exception (e.g. Tierney and Russell, 2009; Tierney et al., 2010; Tyler et al., 2010; Zink et al., 2010; Sun et al., 2011; Sinninghe Damsté et al., 2012; Günther et al., 2013; Naeher et al., 2013; Schoon et al., 2013; Loomis et al., 2014). The previously discussed heterogeneity of the brGDGT distributions of soils from the Loch Lomond catchment area (section 4.1) results in a similarly wide range of MAAT estimates, from 6.0 to $11.7^{\circ} \mathrm{C}$ (CL) (Table 1). However, none of the soils are outside the calibration error of the proxy $\left(5.0^{\circ} \mathrm{C}\right)$, and the mean estimate of $8.2^{\circ} \mathrm{C}$ is close to the annual MAAT of $9.5^{\circ} \mathrm{C}$, well within the calibration error.

MSAT estimates from Loch Lomond lake sediments generated using the Pearson11 lake calibration are fairly accurate, yielding an average of $14 \pm 2{ }^{\circ} \mathrm{C}( \pm \sigma)$, ranging from 11.4 to $17.5^{\circ} \mathrm{C}$ (Table 5), close to the measured MSAT of ca. $15^{\circ} \mathrm{C}$. However, these MSAT estimates are strongly affected by the variation of sedimentary brGDGT distributions by basin, generating lower estimates in the north basins $\left(11.4-13.6^{\circ} \mathrm{C}\right)$ compared with the south basin $(15.0$ $17.5^{\circ} \mathrm{C}$ ), without exception. This is not a product of the particular calibration applied but a result of the differences in brGDGT distribution between the two basins, which, in part, is likely due to the influence of Endrick Water on the south basin.
Despite the production of brGDGTs in Loch Lomond, mean inferred MAATs (or MSATs from Pearson11) from every lake calibration are accurate to within their respective calibration errors (Table 6), regardless of the geographical region on which the calibration data set is based. This suggests that brGDGT-producing bacteria within lake waters and/or sediments show a consistent response to temperature, likely (bottom) water temperature, but are forced to correlate with air temperature. Some lacustrine calibrations of brGDGT distribution with temperature (Zink10 and Sun11; Table 6) follow the rationale of the MBT index and CBT ratio, to be directly related to the biophysical adaptation of brGDGT-producing bacteria to changing ambient temperature and $\mathrm{pH}$ (cf. Weijers et al., 2007a). Other "regression-style" lake calibrations - including Tierney10, Pearson11 and Loomis12 - rely on the statistical selection of brGDGTs that best reflect the variation seen in their calibration data sets. When multiple lacustrine calibrations are applied to this Loch Lomond surface sediment data set, those with regression-style brGDGT selection yield MAAT/MSAT estimates that (without exception) show stronger correlations with water depth (Tierney10: $r^{2}=0.81$; Pearson11: $r^{2}=0.78$; Loomis12: $r^{2}=0.66$; Fig. 9) than those developing MBT- and CBT-style calibrations (Zink10: $r^{2}=0.19$; Sun11: $r^{2}=0.43$; Fig. 9). Although MBT- and CBT-style calibrations still use brGDGTs of mixed provenance, the influence of water depth on inferred temperatures is much reduced, perhaps due to their adherence to the presumed biophysical adaptation of the bacterial producers to temperature and $\mathrm{pH}$. The observed correlation with water depth likely represents the aforementioned riverine influences on shallow south basin sediments, so these regression-style calibrations may be more strongly affected by allochthonous influences here than those using the MBT index and CBT ratio. Although it is not known whether this relationship is peculiar to Loch Lomond, the greater susceptibility of regression-style calibrations to changes in the delivery of allochthonous organic matter to lake sediments would certainly affect the reliability of their inferred temperature records.

This emphasises that, since the proportion of lacustrine production from lake to lake can vary from insignificant (e.g. Lake Cadagno; Niemann et al., 2012) to substantial 

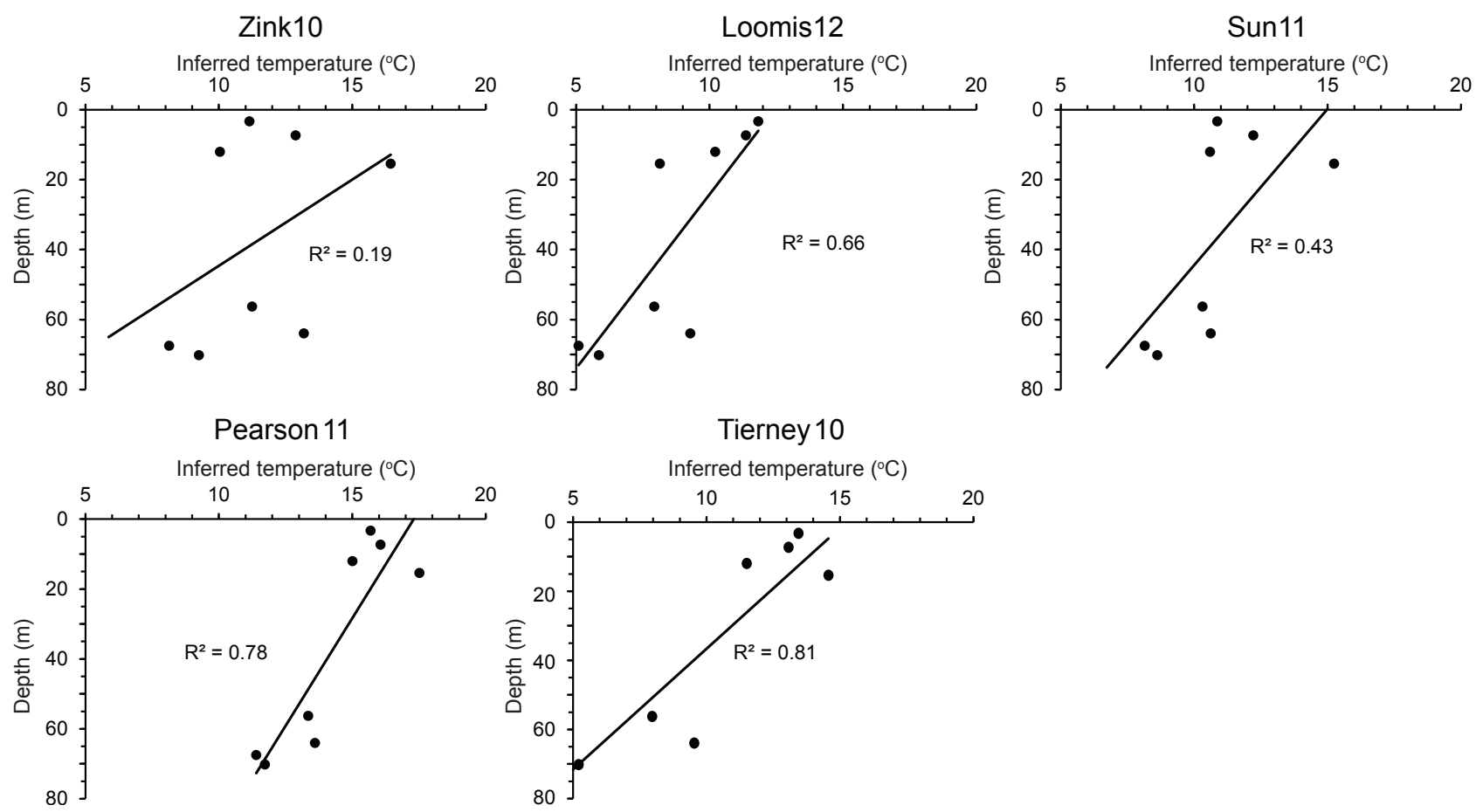

Figure 9. CL-brGDGT-derived MAAT estimates (MSAT in the case of Pearson11) from Loch Lomond surface sediments, against water depth, for the different MBT-CBT lacustrine calibrations (see text).

regardless of region or climatic regime, those attempting to minimise potentially varied contributions of brGDGTs through calibrations of a number of lakes must be vigilant. For example, surface sediments from Lake Challa, which has a relatively small catchment area, have been shown to yield MAATs outside the error of the Tierney10 and Loomis12 MBT-CBT calibrations despite being included in their calibration data sets (Buckles et al., 2014). Although this offset could result from multiple considerations, including interannual changes in community composition and export (e.g. Buckles et al., 2014), the low allochthonous to autochthonous brGDGT ratio for this crater lake likely contributes. Therefore, it should be emphasised that, in practice, all MBT-CBT calibrations of lake sediments will provide a MAAT estimate based on the overall average mixing ratio of autochthonous and allochthonous brGDGT input for that specific set of lakes.

Additionally, significant sedimentary production of brGDGTs, whose distribution will likely be representative of ambient conditions in lake surface sediments rather than of the lake surface, implies that the rationalisation for the calibration of sedimentary brGDGT distributions with air temperature (MSAT or MAAT) is flawed. This includes the ostensibly accurate Pearson11 calibration applied here. In addition to this potentially flawed relationship, another key issue that remains concerns the preservation efficiency of riverine and lacustrine brGDGTs in lake sediments, compared with not only influxes of soil brGDGTs but also with in situ produced sedimentary brGDGTs. Since lake calibrations are all based on modern lake core top sediments, the degradation of a large proportion of in situ produced sedimentary brGDGTs below the first few centimetres of sediment would seriously impact upon these calibrations. When looking at the similarly structured isoprenoidal GDGTs in Aarhus Bay sediments, Weijers et al. (2011) found that in situ produced isoprenoid GDGT core lipids in sediments were preferentially degraded compared with those derived from the water column; Lengger et al. (2012) also concluded that in situ produced isoprenoid GDGTs within Arabian Sea sediments were more susceptible to degradation and so did not accumulate in the CL "pool". In Lake Challa, a decrease in \%IPL of brGDGTs with sediment depth was also attributed to this preferential degradation of potentially in situ produced sedimentary brGDGTs (Buckles et al., 2014). Much is still unknown about the early diagenetic processes, but recycling of sedimentary GDGT lipids, as reported for archaeal (isoprenoid) GDGTs (cf. Takano et al., 2010), might be an important aspect. It is also possible that more labile, in situ produced functionalised lipids may be preferentially incorporated into sedimentary geomacromolecules in comparison to soil-derived CL brGDGTs in sediments which have previously survived the remineralisation process. Considering these findings and the substantial sedimentary production of brGDGTs within Loch Lomond, studies of the degradation of in situ 
produced sedimentary brGDGTs would help to constrain the application of the MBT-CBT proxy.

\subsection{Implications for palaeothermometry in Loch Lomond: TEX $_{86}$}

High BIT indices in marine sediments were thought to be indicative of a high input of soil derived organic matter relative to marine organic matter (e.g. Hopmans et al., 2004; Huguet et al., 2007; Kim et al., 2008a, b; Walsh et al., 2008; Smith et al., 2012). Since soil generally also contains small proportions of isoprenoidal GDGTs, high influxes of soil organic matter to marine sediments can affect aquatic isoprenoidal GDGT distributions and hence bias the $\mathrm{TEX}_{86}$ signal and render this proxy for sea surface temperature reconstruction ineffective at these locations (Weijers et al., 2006b). Similarly, in lake sediments the BIT index has been used to exclude certain sediments from application of the $\mathrm{TEX}_{86}$ lake surface temperature proxy (Blaga et al., 2009). High BIT indices in Loch Lomond SPM and lake sediments would rule out the application of $\mathrm{TEX}_{86}$ using existing guidelines. However, these high BIT indices result, at least partially, from the aforementioned in situ production of brGDGTs rather than solely from soil influxes. This was also shown for Lake Challa, where soil influxes from a small crater catchment were low, while BIT indices in surface sediments approached 1 due to the high proportion of lacustrine brGDGT production (Buckles et al., 2014). Although crenarchaeol is produced within Loch Lomond, this is in low abundance compared with the total brGDGTs found within the lake and its sediments.

Since the catchment area of Loch Lomond is relatively large, there may be comparatively high proportions of isoprenoid GDGTs transported via numerous rivers and streams and flushed into the lake. However, the BIT index in Loch Lomond has been invalidated as a reliable proxy for tracing this soil-derived GDGT input due to the significant in situ production of brGDGTs in the lake (see above). Hence, in some cases it might well be that the $\mathrm{TEX}_{86}$ proxy may still be applicable despite relatively high BIT index values. September SPM from below $30 \mathrm{~m}$ depth in the lower north basin contains a relatively high proportion of crenarchaeol, in comparison to SPM from other locations and seasons (Table 2). Due to the presence of IPL as well as CL crenarchaeol, this indicates current thaumarchaeotal activity in the water column of the lake (e.g. Buckles et al., 2013). Since isoprenoidal IPL GDGT concentrations are low in the SPM (Fig. 8) and as the $\mathrm{TEX}_{86}$ proxy is generally applied to CL GDGTs, we will examine $\mathrm{CL}$ indices only. The lowest BIT index along this profile (between 30 and $60 \mathrm{~m}$ depth, corresponding with the highest crenarchaeol concentrations) is ca. 0.6 , which is well above the 0.3-0.4 level used as a rule-of-thumb cut-off value for $\mathrm{TEX}_{86}$ application (Blaga et al., 2009). TEX 86 indices and corresponding LST estimates (generated using the lake calibration by Powers et al., 2010) in this SPM profile ranged from 6.2 to $7.5^{\circ} \mathrm{C}$ between 30 and $60 \mathrm{~m}$ depth, with an average LST estimate of $6.9^{\circ} \mathrm{C}$ (Table 2, Fig. 8). Measured temperatures at these depths range from 8.8 to $7.2^{\circ} \mathrm{C}$ in September when the SPM was collected, with an average temperature of $7.7^{\circ} \mathrm{C}$. Thus the $\mathrm{TEX}_{86} \mathrm{LST}$ reconstruction is well within the calibration error $\left( \pm 3.6^{\circ} \mathrm{C}\right)$ of the lacustrine $\mathrm{TEX}_{86}$ calibration. It needs to be emphasised, however, that this reconstructed LST does not represent an annual temperature since the SPM represents merely a snapshot of conditions in the water column. In the rest of this profile, temperature estimates track measured in situ temperatures well within the error of estimate (Fig. 8) regardless of high BIT indices up to 0.89 . This indicates that the $\mathrm{TEX}_{86}$ proxy could potentially be applicable throughout the lake.

South basin SPM produces abundance-weighted average LST estimates of $15.3^{\circ} \mathrm{C}$ in March and $14.9^{\circ} \mathrm{C}$ in September. These are not only above measured in situ temperatures (Fig. 3) but also above measured mean annual LST. Lower north basin SPM (March: $12.1^{\circ} \mathrm{C}$; September: $9.2^{\circ} \mathrm{C}$ ) and upper north basin SPM (September: $11.0^{\circ} \mathrm{C}$ ), however, yield LST estimates within the calibration error of measured in situ temperatures. Biased LSTs in the south are probably due to influxes of soil-derived isoprenoid GDGTs, which generally have higher TEX 86 values (mean of 0.57), close to those in south basin SPM (means of 0.53 and 0.52). Perhaps more importantly, crenarchaeol concentrations are also low in the south basin in comparison to the north basins, again meaning that soil influxes contribute a greater proportion of isoprenoid GDGTs to the lake. Although settling particles are a better indicator of GDGT distributions exported to sediment than SPM, these show similarly high flux-weighted average LST estimates in the south basin $\left(13.3\right.$ and $14.0^{\circ} \mathrm{C}$; middle and bottom of water column, respectively) and accurate LST estimates in the lower north basin $\left(9.2^{\circ} \mathrm{C}\right)$. In settling particles from the south basin, crenarchaeol fluxes are not significantly correlated with $\mathrm{TEX}_{86}$. This is likely due to high proportions of soil-derived GDGTs delivered by Endrick Water, which dominates the hydrology of the south basin. However, in the lower north basin without major rivers, crenarchaeol fluxes correlate strongly and negatively with $\operatorname{TEX}_{86}(r=-0.68)$. This implies that crenarchaeol fluxes are the controlling factor determining whether inferred LSTs are accurate; i.e. a high crenarchaeol flux corresponds to lower $\mathrm{TEX}_{86}$ indices as in that case the higher background $\mathrm{TEX}_{86}$ values (from soils and/or rivers) are suppressed. Sediments reflect findings in settling particles; south basin sediments yield a high average $\mathrm{TEX}_{86}$-inferred temperature $\left(15.2^{\circ} \mathrm{C}\right)$, and lower north basin sediments give an average LST within the calibration error $\left(12.0^{\circ} \mathrm{C}\right)$. Upper north basin sediments yield a slightly high average LST estimate $\left(13.6^{\circ} \mathrm{C}\right)$, potentially due to the influence of the River Falloch.

Clearly TEX $_{86}$-derived LST estimates are affected by soil influxes to Loch Lomond, mainly delivered by the major rivers: Endrick Water in the south and the R. Falloch in the north. Settling particles show that, in the lower north basin 
where riverine influences are at a minimum, high fluxes of crenarchaeol are related to more accurate LST estimates, due to soil-derived GDGTs comprising a lower proportion of the total isoprenoid GDGT pool.

The inability to estimate the extent of the potential bias to TEX $_{86}$ using the BIT index means that it is difficult, if not impossible, to ascertain a cut-off for the application of the proxy. Since in situ brGDGT production has been seen in numerous lakes and is likely substantial in the vast majority of lakes, this means that the TEX 86 proxy cannot be safely applied. This must be a widespread issue with the proxy in lakes and argues for the review of a safe cut-off value of the BIT index for $\mathrm{TEX}_{86}$ application in lacustrine sediments. Here, we find that accurate LST estimates from sediments are possible despite BIT indices approaching 1, although changing allochthonous influxes and changes in the productivity of Thaumarchaeota affect the accuracy of these estimates. The only exceptions to this are a low BIT index - i.e. following current guidelines this would require a BIT index below 0.4 (Blaga et al., 2009) - or a detailed validation study using sediment trap data to calculate crenarchaeol concentrations and fluxes.

There is a case in Loch Lomond for applying TEX $_{86}$ in the lower north basin and setting a cut-off value for crenarchaeol concentrations, rather than using the BIT index. However, a more detailed validation study, including investigation of a sediment record with respect to the variation of TEX86 indices with crenarchaeol concentration, is recommended before setting a concrete cut-off for Loch Lomond and before concluding that the proxy is safely applicable.

\section{Conclusions}

The origins of brGDGTs deposited in Loch Lomond sediments are complex. Contributions of brGDGTs reach lake sediments from soils, rivers and streams, from throughout the water column of the lake and the lake sediments themselves. This study identifies the occurrence of in situ production of brGDGTs within larger temperate lakes, in addition to earlier-reported smaller and tropical lakes. Most notably, in Loch Lomond the lacustrine-produced brGDGTs form a substantial proportion of the total brGDGT pool in sediments, despite the soil CL brGDGT signature originating from a large, soil-organic-matter-rich catchment area. BrGDGT distributions from Loch Lomond sediments are strongly shifted away from the distributions found in surrounding soils, rivers and the lake's water column, indicating that in situ production within the sediments is particularly abundant. Moreover, this difference in brGDGT distributions suggests either that different groups of bacteria are responsible for the production of branched GDGTs within each of these environments or that a shift in the community structure (i.e. the dominant species) of brGDGT-producing bacteria is responsible for the different brGDGT distributions found in each setting.
The accumulated research on brGDGT distributions in lakes, including this study, has strong implications for the application of the MBT-CBT palaeotemperature proxy to lake sedimentary archives. A lake calibration by Pearson et al. (2011) generated MSAT estimates within the calibration error, although these estimates varied by basin due to shifts in sedimentary brGDGT distributions along a south-to-north gradient. Lower inferred temperatures from more northerly sediments may (amongst others) be due to the influence of allochthonous brGDGTs delivered to south basin sediments by Endrick Water and/or the effect of increasing depth on the lake calibration.

Due to the multiple conflicting factors affecting the application of the MBT-CBT palaeotemperature proxy in lakes, it would be desirable to undertake modern investigations of the origin and distributions of brGDGTs found in the catchment soils, water column and sediments of each lake prior to the application of a suitable lacustrine calibration. However, the preservation potential of brGDGTs of different origins cannot be assumed to be equal, so a modern investigation may not identify these issues. Multiple proxies should also be applied to lake sediments archives where possible, so that offsets and deviations in inferred MAATs that do not correspond to "real" temperatures can be identified. This means that the uncertainties associated with the application of the MBT-CBT palaeotemperature proxy in lakes can be reduced.

The significant in situ production of brGDGTs in Loch Lomond nullifies the use of the BIT index as a proxy for soil organic matter. Hence, the cut-off BIT index value used to determine the applicability of $\mathrm{TEX}_{86}$ no longer applies. Since there is still no other way to identify excess input of soil-derived isoprenoid GDGTs, application of $\mathrm{TEX}_{86}$ at higher BIT index values remains precarious and is not recommended. 


\section{Appendix A}

Table A1. Results of a MANOVA analysis (multivariate analysis of variance) and subsequent Tukey's HSD procedures. The mean difference between sample groups (in units of fractional abundance) and associated $p$ values are shown here for each brGDGT; where the null hypothesis was accepted (denoted NHA), no Tukey's HSD procedures were performed. Samples and numbers in bold denote statistically significant differences $(p<0.10)$.

\begin{tabular}{|c|c|c|c|c|c|c|c|c|c|c|c|c|c|c|c|}
\hline \multicolumn{2}{|c|}{$\begin{array}{l}\text { Sample group comparison } \\
\text { (CL) }\end{array}$} & $\begin{array}{l}1022 \\
\text { GDGT } \\
\text { VI } \\
\bar{x}-\bar{y}\end{array}$ & $\begin{array}{l}1022 \\
\text { GDGT } \\
\text { VI } \\
p\end{array}$ & $\begin{array}{l}1020 \\
\text { GDGT } \\
\text { VIb } \\
\bar{x}-\bar{y}\end{array}$ & $\begin{array}{l}1020 \\
\text { GDGT } \\
\text { VIb } \\
p\end{array}$ & $\begin{array}{l}1018 \\
\text { GDGT } \\
\text { VIc } \\
\bar{x}-\bar{y}\end{array}$ & $\begin{array}{l}1018 \\
\text { GDGT } \\
\text { VIc } \\
p \text { value }\end{array}$ & $\begin{array}{l}1036 \\
\text { GDGT } \\
\text { VII } \\
\bar{x}-\bar{y}\end{array}$ & $\begin{array}{l}1036 \\
\text { GDGT } \\
\text { VII } \\
p\end{array}$ & $\begin{array}{l}1034 \\
\text { GDGT } \\
\text { VIIb } \\
\bar{x}-\bar{y}\end{array}$ & $\begin{array}{l}1034 \\
\text { GDGT } \\
\text { VIIb } \\
p\end{array}$ & $\begin{array}{l}1032 \\
\text { GDGT } \\
\text { VIIc } \\
\bar{x}-\bar{y}\end{array}$ & $\begin{array}{l}1032 \\
\text { GDGT } \\
\text { VIIc } \\
p\end{array}$ & $\begin{array}{l}1050 \\
\text { GDGT } \\
\text { VIII } \\
\bar{x}-\bar{y}\end{array}$ & $\begin{array}{l}1050 \\
\text { GDGT } \\
\text { VIII } \\
p\end{array}$ \\
\hline River SPM & Soil & -0.078 & 0.016 & -0.006 & 0.655 & & & 0.028 & 0.435 & 0.005 & 0.882 & 0.001 & 0.607 & 0.052 & 0.035 \\
\hline River sediment & Soil & -0.094 & 0.000 & -0.003 & 0.936 & & & 0.038 & 0.047 & 0.009 & 0.260 & 0.002 & 0.173 & 0.049 & 0.017 \\
\hline Lake SPM & Soil & -0.061 & 0.000 & -0.009 & 0.003 & & & 0.011 & 0.797 & 0.005 & 0.546 & 0.002 & 0.050 & 0.054 & 0.000 \\
\hline $\begin{array}{l}\text { Settling } \\
\text { particles }\end{array}$ & Soil & -0.058 & 0.002 & -0.005 & 0.479 & & & -0.001 & 1.000 & 0.010 & 0.007 & 0.002 & $\mathbf{0 . 0 3 7}$ & 0.052 & 0.000 \\
\hline Lake sediment & Soil & -0.147 & 0.000 & -0.002 & 0.993 & & & -0.056 & 0.000 & 0.026 & 0.000 & 0.004 & 0.000 & 0.167 & 0.000 \\
\hline Lake sediment & River SPM & -0.069 & 0.082 & 0.004 & 0.915 & & & -0.084 & 0.000 & 0.021 & 0.001 & 0.003 & 0.072 & 0.114 & 0.000 \\
\hline Lake sediment & River sediment & -0.054 & 0.166 & 0.002 & 0.999 & & & -0.094 & 0.000 & 0.017 & 0.003 & 0.002 & 0.098 & 0.118 & 0.000 \\
\hline Lake sediment & Lake SPM & -0.087 & 0.000 & 0.008 & 0.105 & & & -0.067 & 0.000 & 0.021 & 0.000 & 0.003 & 0.001 & 0.113 & 0.000 \\
\hline Lake sediment & $\begin{array}{l}\text { Settling } \\
\text { particles }\end{array}$ & -0.089 & 0.000 & 0.003 & 0.946 & & & -0.054 & 0.000 & 0.016 & 0.000 & 0.002 & 0.004 & 0.114 & 0.000 \\
\hline $\begin{array}{l}\text { Settling } \\
\text { particles }\end{array}$ & River sediment & 0.036 & 0.412 & -0.001 & 0.999 & & & -0.040 & 0.019 & 0.001 & 0.999 & 0.000 & 1.000 & 0.003 & 1.000 \\
\hline River sediment & River SPM & -0.015 & 0.993 & 0.003 & 0.989 & & & 0.010 & 0.990 & 0.004 & 0.982 & 0.000 & 0.998 & -0.003 & 1.000 \\
\hline Lake SPM & River SPM & 0.018 & 0.964 & -0.003 & 0.965 & & & -0.017 & 0.838 & -0.001 & 1.000 & 0.000 & 1.000 & 0.002 & 1.000 \\
\hline Settling particles & River SPM & 0.021 & 0.937 & 0.002 & 0.997 & & & -0.029 & 0.319 & 0.005 & 0.855 & 0.000 & 1.000 & 0.000 & 1.000 \\
\hline Lake SPM & River sediment & 0.033 & 0.481 & -0.006 & 0.429 & & & -0.027 & 0.211 & -0.004 & 0.862 & 0.000 & 0.997 & 0.005 & 0.999 \\
\hline $\begin{array}{l}\text { Settling } \\
\text { particles }\end{array}$ & Lake SPM & 0.003 & 1.000 & 0.005 & 0.159 & & & -0.013 & 0.527 & 0.006 & 0.144 & 0.000 & 1.000 & -0.001 & 1.000 \\
\hline River SPM & Soil & -0.026 & 0.896 & $\mathrm{NH}$ & & & & -0.008 & 0.999 & 0.009 & 0.737 & & & 0.031 & 0.680 \\
\hline River sediment & Soil & -0.059 & 0.066 & $\mathrm{NH}$ & & & & 0.028 & 0.745 & 0.014 & 0.121 & & & 0.016 & 0.946 \\
\hline Lake SPM & Soil & -0.042 & 0.046 & $\mathrm{NH}$ & & & & -0.008 & 0.991 & 0.013 & 0.009 & & & 0.041 & 0.018 \\
\hline $\begin{array}{l}\text { Settling } \\
\text { particles }\end{array}$ & Soil & -0.029 & 0.376 & $\mathrm{NH}$ & & & & -0.028 & 0.390 & 0.015 & 0.003 & & & 0.049 & 0.003 \\
\hline Lake sediment & Soil & -0.130 & 0.000 & $\mathrm{NH}$ & & & & -0.100 & 0.000 & 0.033 & 0.000 & & & 0.187 & 0.000 \\
\hline Lake sediment & River SPM & -0.105 & 0.001 & $\mathrm{NH}$ & & & & -0.092 & 0.006 & 0.024 & 0.008 & & & 0.156 & 0.000 \\
\hline Lake sediment & River sediment & -0.071 & 0.027 & $\mathrm{NH}$ & & & & -0.128 & 0.000 & 0.019 & 0.025 & & & 0.171 & 0.000 \\
\hline Lake sediment & Lake SPM & -0.088 & 0.000 & $\mathrm{NH}$ & & & & -0.092 & 0.000 & 0.020 & 0.000 & & & 0.146 & 0.000 \\
\hline Lake sediment & $\begin{array}{l}\text { Settling } \\
\text { particles }\end{array}$ & -0.101 & 0.000 & $\mathrm{NH}$ & & & & -0.072 & 0.001 & 0.018 & 0.002 & & & 0.138 & 0.000 \\
\hline $\begin{array}{l}\text { Settling } \\
\text { particles }\end{array}$ & River sediment & 0.030 & 0.625 & $\mathrm{NH}$ & & & & -0.056 & 0.041 & 0.001 & 1.000 & & & 0.033 & 0.352 \\
\hline River sediment & River SPM & -0.033 & 0.821 & $\mathrm{NH}$ & & & & 0.036 & 0.738 & 0.005 & 0.976 & & & -0.015 & 0.989 \\
\hline Lake SPM & River SPM & -0.017 & 0.975 & $\mathrm{NH}$ & & & & 0.000 & 1.000 & 0.004 & 0.974 & & & 0.010 & 0.996 \\
\hline $\begin{array}{l}\text { Settling } \\
\text { particles }\end{array}$ & River SPM & -0.003 & 1.000 & $\mathrm{NH}$ & & & & -0.019 & 0.949 & 0.006 & 0.890 & & & 0.018 & 0.934 \\
\hline Lake SPM & River sediment & 0.017 & 0.948 & $\mathrm{NH}$ & & & & -0.036 & 0.357 & -0.001 & 1.000 & & & 0.024 & 0.658 \\
\hline $\begin{array}{l}\text { Settling } \\
\text { particles }\end{array}$ & Lake SPM & 0.013 & 0.856 & $\mathrm{NH}$ & & & & -0.019 & 0.507 & 0.002 & 0.986 & & & 0.009 & 0.954 \\
\hline
\end{tabular}


Isoprenoid GDGTs

I

(BDGT-0

II

III

IV

(c)

${ }^{{ }^{\circ}}$

Branched GDGTs

II

(1020

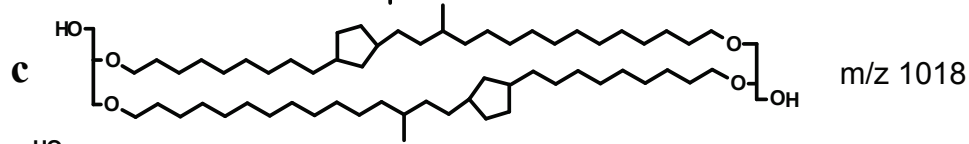

VII

(1034)

(1032)

VIII ${ }^{\text {HOCOH }}$

(1)

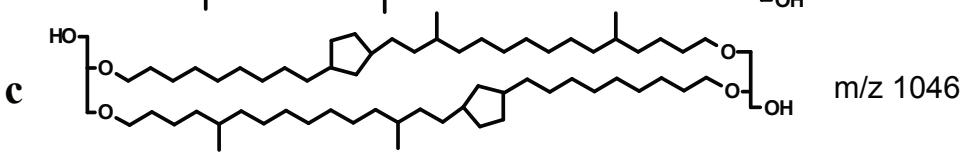

Figure A1. GDGT structures. 
Acknowledgements. We would like to thank everyone at the Scottish Centre for Ecology and the Natural Environment (SCENE) who provided us with fieldwork support and would like to thank D. van de Meent and H. Murray for analytical assistance. J. Bendle provided us with invaluable input and support through planning. The research leading to these results has received funding from the European Research Council under the European Union's Seventh Framework Programme (FP7/2007-2013)/ERC grant agreement no. (226600). J. W. H. Weijers would like to acknowledge funding through a Veni grant from the Netherlands Organisation for Scientific Research (NWO).

Edited by: N. Ohkouchi

\section{References}

Bauersachs, T., Speelman, E. N., Hopmans, E. C., Reichart, G., Schouten, S., and Sinninghe Damsté, J. S.: Fossilized glycolipids reveal past oceanic $\mathrm{N}_{2}$ fixation by heterocystous cyanobacteria. P. Natl. Acad. Sci. USA, 107, 19190-19194, 2010.

Bayfield, N. G. and Conroy J. W. H. (Eds.): Ecological Assessment of Loch Lomond Water Management Proposals, Report to Central Scotland Water Development Board by Centre for Ecology and Hydrology (NERC), available at: http://www.ceh.ac.uk/ staffarchive/cr/t02050/x1/o148817cr.pdf (last access: 23 December 2013), 1995.

Bechtel, A., Smittenberg, R. H., Bernasconi, S. M., and Schubert, C. J.: Distribution of branched and isoprenoid tetraether lipids in an oligotrophic and a eutrophic Swiss lake: insights into sources and GDGT-based proxies, Org. Geochem., 41, 822-832, 2010.

Best, G. A. and Traill, I.: The physico-chemical limnology of Loch Lomond, Hydrobiologia, 290, 29-37, 1994.

Birse, E. L.: The assessment of climatic conditions, in: Scotland, 3. Bio-climatic Sub-regions, The Macaulay Institute for Soil Research, Craigiebuckler, Aberdeen, 1971.

Blaga, C. I., Reichart, G. J., Heiri, O., and Sinninghe Damsté, J. S.: Tetraether membrane lipid distributions in water-column particulate matter and sediments: a study of 47 European lakes along a north-south transect, J. Paleolimnol., 41, 523-540, 2009.

Blaga, C. I., Reichart, G., Schouten, S., Lotter, A. F., Werne, J. P., Kosten, S., Mazzeo, N., Lacerot, G., and Sinninghe Damsté, J. S.: Branched glycerol dialkyl glycerol tetraethers in lake sediments: can they be used as temperature and $\mathrm{pH}$ proxies?, Org. Geochem., 41, 1225-1234, 2010.

Buckles, L. K., Villanueva, L., Weijers, J. W. H., Verschuren, D., and Sinninghe Damsté, J. S.: Linking isoprenoidal GDGT membrane-lipid distributions with gene abundances of ammoniaoxidising Thaumarchaeota and uncultured crenarchaeotal groups in the water column of a tropical lake (Lake Challa, East Africa), Environ. Microbiol., 15, 2445-2462, doi:10.1111/14622920.12118, 2013.

Buckles, L. K., Weijers, J. W. H., Verschuren, D., and Sinninghe Damsté, J. S.: Sources of core and intact branched tetraether membrane lipids in the lacustrine environment: anatomy of Lake Challa and its catchment, East Africa, Geochim. Cosmochim, Ac., 140, 106-126, 2014.

Curran, J. C. and Poodle, T.: Aspects of the hydrology and hydrography of Loch Lomond, Hydrobiologia, 290, 21-28, 1994.
Das, S. K., Bendle, J., and Routh, J.: Evaluating branched tetraether lipid-based palaeotemperature proxies in an urban, hyper-eutrophic polluted lake in South Africa, Org. Geochem., 53, 45-51, 2012.

Edwards, R. T. and Meyer, J. L.: Production and Turnover of Planktonic Bacteria in two Southeastern Blackwater Rivers, Appl. Environ. Microbiol., 52, 1317-1323, 1986.

Eurolakes consortium: Integrated Water Resource Management for Important Deep European Lakes and their Catchment Areas: Site Characterisation, EC Framework Programme, 5, Deliverable D5, available at: http://www.hydromod.de/Eurolakes/ (last access: 07 March 2011), 2001.

Gibson, R. A., van der Meer, M. T. J., Hopmans, E. C., Reysenbach, A., Schouten, S., and Sinninghe Damsté, J. S.: Comparison of intact polar lipid with microbial community composition of vent deposits of the Rainbow and Lucky Strike hydrothermal fields, Geobiology, 11, 72-85, 2013.

Günther, F., Thiele, A., Gleixner, G., Xu, B., Yao, T., and Schouten, S.: Distribution of bacterial and archaeal ether lipids in soils and surface sediments of Tibetan lakes: implications for GDGT-based proxies in saline high mountain lakes, Org. Geochem, 67, 19-30, 2014.

Hopmans, E. C., Weijers, J. W. H., Schefuss, E., Herfort, L., Sinninghe Damsté, J. S., and Schouten, S.: A novel proxy for terrestrial organic matter in sediments based on branched and isoprenoid tetraether lipids, Earth Planet. Sc. Lett., 224, 107-116, 2004.

Huguet, C., Hopmans, E. C., Febo-Ayala, W., Thompson, D. H., Sinninghe Damsté, J. S., and Schouten, S.: An improved method to determine the absolute abundance of glycerol dibiphytanyl glycerol tetraether lipids, Org. Geochem., 37, 1036-1041, 2006.

Huguet, C., Schimmelmann, A., Thunell, R., Lourens, L. J., Sinninghe Damsté, J. S., and Schouten, S.: A study of the TEX 86 paleothermometer in the water column and sediments of the Santa Barbara Basin, California, Paleoceanography, 22, PA3203, doi:10.1029/2006PA001310, 2007.

Kim, J. H., Buscail, R., Bzarzycka, B., Kerherve, P., Peterse, F., Schouten, S., Ludwig, W., and Sinninghe Damsté, J. S.: Tracking soil organic matter export across the continent-ocean interface: a case study of the NW Mediterranean using the BIT index, Geochim. Cosmochim. Ac., 72, A472-A472, 2008a.

Kim, J. H., Schouten, S., Hopmans, E. C., Donner, B., and Sinninghe Damsté, J. S.: Global sediment core-top calibration of the TEX $_{86}$ paleothermometer in the Ocean, Geochim. Cosmochim. Ac., 72, 1154-1173, 2008b.

Kim, J., Zell, C., Moreira-Turcq, P., Pérez M. A. P., Abril, G., Mortillaro, J., Weijers, J. W. H., Meziane, T., and Sinninghe Damsté, J. S.: Tracing soil organic carbon in the lower Amazon River and its tributaries using GDGT distributions and bulk organic matter properties, Geochim. Cosmochim. Ac., 90, 163180, 2012.

Lengger, S. K., Hopmans, E. C., Sinninghe Damsté, J. S., and Schouten, S.: Comparison of extraction and work up techniques for analysis of core and intact polar tetraether lipids from sedimentary environments, Org. Geochem., 47, 34-40, 2012.

Lipp, J. S. and Hinrichs, K.: Structural diversity and fate of intact polar lipids in marine sediments, Geochim. Cosmochim. Ac., 73, 6816-6833, 2009. 
Loomis, S. E., Russell, J. M., and Sinninghe Damsté, J. S.: Distributions of branched GDGTs in soils and lake sediments from western Uganda: implications for a lacustrine paleothermometer, Org. Geochem., 42, 739-751, 2011.

Loomis, S. E., Russell, J. M., Ladd, B., Street-Perrott, F. A., and Sinninghe Damsté, J. S.: Calibration and application of the branched GDGT temperature proxy on East African lake sediments, Earth Planet. Sc. Lett., 357-358, 277-288, 2012.

Loomis, S. E., Russell, J. M., Eggermont, H., Verschuren, D., and Sinninghe Damsté, J. S.: Effects of temperature, $\mathrm{pH}$ and nutrient concentration on branched GDGT distributions in East African lakes: implications for paleoenvironmental reconstruction, Org. Geochem., 66, 25-37, 2014.

Maitland, P. S. (Ed.): The Ecology of Scotland's Largest Lochs: Lomond, Awe, Ness, Morar and Shiel, Dr. W. Junk Publishers, The Hague, 1981.

Maitland, P. S., Adams, C. E., and Mitchell, J.: The natural heritage of Loch Lomond: its importance in a national and international context, Scott. Geogr. J., 116, 181-196, 2000.

Mohamad Hamza, F.: Statistical Analysis of Freshwater Parameters Monitored at Different Temporal Resolutions, Ph.D. thesis, University of Glasgow, 2012.

Naeher, S., Peterse, F., Smittenberg, R. H., Niemann, H., Zigah, P. K., and Schubert, C. J.: Sources of glycerol dialkyl glycerol tetraethers (GDGTs) in catchment soils, water column and sediments of Lake Rotsee (Switzerland) - Implications for the application of GDGT-based proxies for lakes, Org. Geochem, 66, 164-173, 2014.

Niemann, H., Stadnitskaia, A., Wirth, S. B., Gilli, A., Anselmetti, F. S., Sinninghe Damsté, J. S., Schouten, S., Hopmans, E. C., and Lehmann, M. F.: Bacterial GDGTs in Holocene sediments and catchment soils of a high Alpine lake: application of the MBT / CBT-paleothermometer, Clim. Past, 8, 889906, doi:10.5194/cp-8-889-2012, 2012.

Pearson, E. J., Juggins, S., Talbot, H. M., Weckström J., Rosén P., Ryves, D. B., Roberts, S. J., and Schmidt, R.: A lacustrine GDGT-temperature calibration from the Scandinavian Arctic to Antarctic: renewed potential for the application of GDGTpaleothermometry in lakes, Geochim. Cosmochim. Ac., 75, 6225-6238, 2011.

Peterse, F., van der Meer, J., Schouten, S., Weijers, J. W. H., Fierer, N., Jackson, R. B., Kim, J., and Sinninghe Damsté, J. S.: Revised calibration of the MBT-CBT paleotemperature proxy based on branched tetraether membrane lipids in surface soils, Geochim. Cosmochim. Ac., 96, 215-229, 2012.

Pierce, L.: Loch Lomond: an example of quaternary megageomorphology, Scott. Geogr. J., 115, 71-80, 1999.

Pitcher, A., Hopmans, E. C., Schouten, S., and Sinninghe Damsté, J. S.: Separation of core and intact polar archaeal tetraether lipids using silica columns: insights into living and fossil biomass contributions, Org. Geochem., 40, 12-19, 2009a.

Pitcher, A., Schouten, S., and Sinninghe Damsté, J. S.: In situ production of crenarchaeol in two California hot springs, Appl. Environ. Microb., 75, 4443-4451, 2009b.

Pitcher, A., Villanueva, L., Hopmans, E. C., Schouten, S., Reichart, G.-J., and Sinninghe Damsté, J. S.: Niche segregation of ammonia-oxidizing archaea and annamox bacteria in the Arabian Sea oxygen minimum zone, ISME. J., 5, 1896-1904, 2011a.
Pitcher, A., Hopmans, E. C., Mosier, A. C., Park, S., Rhee, S., Francis, C. A., Schouten, S., and Sinninghe Damsté, J. S.: Core and intact polar glycerol dibiphytanyl glycerol tetraether lipids of ammonia-oxidizing archaea enriched from marine and estuarine sediments, Appl. Environ. Microb., 77, 3468-3477, 2011 b.

Powers, L., Werne, J. P., Vanderwoude, A. J., Sinninghe Damsté, J. S., Hopmans, E. C., and Schouten, S.: Applicability and calibration of the $\mathrm{TEX}_{86}$ paleothermometer in lakes, Org. Geochem., 41, 404-413, 2010.

Schoon, P. L., de Kluijver, A., Middelburg, J. J., Downing, J. A., Sinninghe Damsté, J. S., and Schouten, S.: Influence of lake water $\mathrm{pH}$ and alkalinity on the distribution of core and intact polar branched glycerol dialkyl glycerol tetraethers (GDGTs) in lakes, Org. Geochem., 60, 72-82, 2013.

Schouten, S., Huguet, C., Hopmans, E. C., Kienhuis, M. V. M., and Sinninghe Damsté, J. S.: Analytical methodology for TEX 86 paleothermometry by high-performance liquid chromatography/atmospheric pressure chemical ionization-mass spectrometry, Anal. Chem., 79, 2940-2944, 2007.

Schouten, S., Eldrett, J., Greenwood, D. R., Harding, I., Baas, M., and Sinninghe Damsté, J. S.: Onset of long-term cooling of Greenland near the Eocene-Oligocene boundary as revealed by branched tetraether lipids, Geology, 36, 147-150, 2008.

Schouten, S., Middelburg, J. J., Hopmans, E. C., and Sinninghe Damsté, J. S.: Fossilization and degradation of intact polar lipids in deep subsurface sediments: a theoretical approach, Geochim. Cosmochim. Ac., 74, 3806-3814, 2010.

Schouten, S., Pitcher, A., Hopmans, E. C., Villanueva, L., van Bleijswijk, J., and Sinninghe Damsté, J. S.: Intact polar and core glycerol dibiphytanyl glycerol tetraether lipids in the Arabian Sea oxygen minimum zone: I. Selective preservation and degradation in the water column and consequences for the $\mathrm{TEX}_{86}$, Geochim. Cosmochim. Ac., 98, 228-243, 2012.

Schouten, S., Hopmans, E. C., Schefuß, E., and Sinninghe Damsté, J. S.: Distributional variations in marine crenarchaeotal membrane lipids: a new tool for reconstructing ancient sea water temperatures?, Earth Planet. Sci. Lett., 204, 265-274, 2002.

Schubotz, F., Wakeham, S. G., Lipp, J. S., Fredricks, H. F., and Hinrichs, K.: Detection of microbial biomass by intact polar membrane lipid analysis in the water column and surface sediments of the Black Sea, Environ. Microbiol., 11, 2720-2734, 2009.

Shanahan, T. M., Hughen, K.A., and Van Mooy, B. A. S.: Temperature sensitivity of branched and isoprenoid GDGTs in Arctic lakes, Org. Geochem., 64, 119-128, 2013.

Sinninghe Damsté, J. S., Ossebaar, J., Abbas, B., Schouten, S., and Verschuren, D.: Fluxes and distribution of tetraether lipids in an equatorial African lake: constraints on the application of the TEX $_{86}$ palaeothermometer and BIT index in lacustrine settings, Geochim. Cosmochim. Ac., 73, 4232-4249, 2009.

Sinninghe Damsté, J. S., Rijpstra, W. I. C., Hopmans, E. C., Weijers, J. W. H., Foesel, B. U., Overmann, J., and Dedysh, S. N.: 13,16-Dimethyl Octacosanedioic acid (iso-diabolic acid): a common membrane-spanning lipid of Acidobacteria subdivisions, 1 and, 3, Appl. Environ. Microb., 77, 4147-4154, 2011.

Sinninghe Damsté, J. S., Ossebaar, J., Schouten, S., and Verschuren, D.: Distribution of tetraether lipids in the $25 \mathrm{ka}$ sedimentary record of Lake Challa: extracting reliable $\mathrm{TEX}_{86}$ and MBT / CBT palaeotemperatures from an equatorial African lake, Quaternary Sci. Rev., 50, 43-54, 2012. 
Slack, H. D.: Studies on Loch Lomond 1, Blackie and Son Ltd, Glasgow, 1957.

Smith, B. D., Cuttle, S. P., and Maitland, P. S.: The profundal zoobenthos, in: The Ecology of Scotland's Largest Lochs: Lomond, Awe, Ness, Morar and Shiel, edited by: Maitland, P. S., Dr. W. Junk Publishers, The Hague, 205-222, 1981a.

Smith, B. D., Maitland, P. S., Young, M. R., and Carr, M. J.: The littoral zoobenthos, in: The Ecology of Scotland's Largest Lochs: Lomond, Awe, Ness, Morar and Shiel, edited by: Maitland, P. S., Dr. W. Junk Publishers, The Hague, 155-203, 1981 b.

Smith, R. W., Bianchi, T. S., and Li, X.: A re-evaluation of the use of branched GDGTs as terrestrial biomarkers: implications for the BIT Index, Geochim. Cosmochim. Ac., 80, 14-29, 2012.

Sun, Q., Chu, G., Liu, M., Xie, M., Li, S., Ling, Y., Wang, X., Shi, L., Jia, G., and Lue, H.: Distributions and temperature dependence of branched glycerol dialkyl glycerol tetraethers in recent lacustrine sediments from China and Nepal, J. Geophys. Res.-Biogeosci., 116, G01008, doi:10.1029/2010JG001365, 2011.

Takano, Y., Chikaraishi, Y., Ogawa, N. O., Nomaki, H., Morono, Y., Inagaki, F., Kitazato, H., Hinrichs, K., and Ohkouchi, N.: Sedimentary membrane lipids recycled by deep-sea benthic archaea, Nat. Geosci., 3, 858-861, 2010.

Tierney, J. E. and Russell, J. M.: Distributions of branched GDGTs in a tropical lake system: implications for lacustrine application of the MBT / CBT paleoproxy, Org. Geochem., 40, 1032-1036, 2009.

Tierney, J. E., Russell, J. M., Eggermont, H., Hopmans, E. C., Verschuren, D., and Sinninghe Damsté, J. S.: Environmental controls on branched tetraether lipid distributions in tropical East African lake sediments, Geochim. Cosmochim. Ac., 74, 49024918, 2010.

Tierney, J. E., Schouten, S., Pitcher, A., Hopmans, E. C., and Sinninghe Damsté, J. S.: Core and intact polar glycerol dialkyl glycerol tetraethers (GDGTs) in Sand Pond, Warwick, Rhode Island (USA): insights into the origin of lacustrine GDGTs, Geochim. Cosmochim. Ac., 77, 561-581, 2012.

Tyler, J. J., Nederbragt, A. J., Jones, V. J., and Thurow, J. W.: Assessing past temperature and soil $\mathrm{pH}$ estimates from bacterial tetraether membrane lipids: evidence from the recent lake sediments of Lochnagar, Scotland, J. Geophys. Res.-Biogeo., 115, G01015, doi:10.1029/2009JG001109, 2010.
Walsh, E. M., Ingalls, A. E., and Keil, R. G.: Sources and transport of terrestrial organic matter in Vancouver Island fjords and the Vancouver-Washington Margin: a multiproxy approach using $\delta 13$ Corg, lignin phenols, and the ether lipid BIT index, Limnol. Oceanogr., 53, 1054-1063, 2008.

Weijers, J. W. H., Schouten, S., Hopmans, E. C., Geenevasen, J. A. J., David, O. R. P., Coleman, J. M., Pancost, R. D., and Sinninghe Damsté, J. S.: Membrane lipids of mesophilic anaerobic bacteria thriving in peats have typical archaeal traits, Environ. Microbiol., 8, 648-657, 2006a.

Weijers, J. W. H., Schouten, S., Spaargaren, O. C., and Sinninghe Damsté, J. S.: Occurrence and distribution of tetraether membrane lipids in soils: implications for the use of the $\mathrm{TEX}_{86}$ proxy and the BIT index, Org. Geochem., 37, 1680-1693, $2006 \mathrm{~b}$.

Weijers, J. W. H., Schouten, S., van den Donker, J. C., Hopmans, E. C., and Sinninghe Damsté, J. S.: Environmental controls on bacterial tetraether membrane lipid distribution in soils, Geochim. Cosmochim. Ac., 71, 703-713, 2007 a.

Weijers, J. W. H., Schouten, S., Sluijs, A., Brinkhuis, H., and Sinninghe Damsté, J. S.: Warm arctic continents during the Palaeocene-Eocene thermal maximum, Earth Planet. Sc. Lett., 261, 230-238, 2007b.

Weijers, J. W. H., Schefuss, E., Schouten, S., and Sinninghe Damsté, J. S.: Coupled thermal and hydrological evolution of tropical Africa over the last deglaciation, Science, 315, 17011704, 2007c.

Weijers, J. W. H., Steinmann, P., Hopmans, E. C., Schouten, S., and Sinninghe Damsté, J. S.: Bacterial tetraether membrane lipids in peat and coal: testing the MBT-CBT temperature proxy for climate reconstruction, Org. Geochem., 42, 477-486, 2011.

Xie, S., Lipp, J. S., Wegener, G., Ferdelman, T. G., and Hinrichs, K.: Turnover of microbial lipids in the deep biosphere and growth of benthic archaeal populations, P. Natl. Acad. Sci. USA, 110, 6010-6014, 2013

Zell, C., Kim, J.-H., Moreira-Turcq, P., Abril, G., Hopmans, E. C., Bonnet, M.-P., Sobrinho, R. L., and Sinninghe Damsté, J. S.: Disentangling the origins of branched tetraether lipids and crenarchaeol in the lower Amazon River: implications for GDGT-based proxies, Limnol. Oceanogr., 58, 343-353, 2013.

Zink, K., Vandergoes, M. J., Mangelsdorf, K., DieffenbacherKrall, A. C., and Schwark, L.: Application of bacterial glycerol dialkyl glycerol tetraethers (GDGTs) to develop modern and past temperature estimates from New Zealand lakes, Org. Geochem., 41, 1060-1066, 2010. 